\title{
LA NATURALEZA JURÍDICA DE LA ACCIÓN REDHIBITORIA EN EL CÓDIGO CIVIL CHILENO: ¿NULIDAD RELATIVA, RESOLUCIÓN POR INCUMPLIMIENTO O RESCISIÓN PROPIAMENTE TAL?
}

\author{
THE LEGAL NATURE OF THE REDHIBITORY ACTION IN THE \\ CHILEAN CIVIL CODE: RELATIVE NULLITY, TERMINATION FOR \\ BREACH OF CONTRACT OR RESCISSION STRICTO SENSU?
}

\section{Patricia López Díaz*}

RESUMEN: El presente trabajo tiene por finalidad abordar la naturaleza jurídica de la acción redhibitoria y proponer un nuevo enfoque inexplorado en la civilística chilena que sugiere concebirla como una acción rescisoria, desplazando su análisis a la fase precontractual, ampliando el sistema de acciones del comprador y contribuyendo a fortalecer el ejercicio de su derecho de opción frente a la existencia de vicios redhibitorios.

Palabras clave: Acción redhibitoria, resolución por incumplimiento, nulidad relativa, rescisión stricto sensu, rescisión por lesión enorme.

ABSTRACT: This work is aimed to address the legal nature of the redhibitory action regarding the sales contract to propose a new approach unexplored by the Chilean civil doctrine that suggests conceiving it as a rescission action. This will shift the analysis to a pre-contractual phase, extending the buyer's actions system, and helping the buyer to strengthen its right of option when facing redhibitory defects.

Key words: Redhibitory action, termination for breach of contract, relative nullity, rescission stricto sensu, rescission because of laesio enormis.

\section{INTRODUCCIÓN}

En el último tiempo la doctrina nacional y comparada no solo ha focalizado su atención en la noción de vicios redhibitorios ${ }^{1}$ o en su prueba ${ }^{2}$, sino que se ha referido par-

\footnotetext{
* Doctora en Derecho Pontificia Universidad Católica de Valparaíso. Profesora de Derecho Civil de la Universidad de Valparaíso. Dirección Postal: Errázuriz 2120, Valparaíso, Chile. Dirección electrónica: patriciaveronica.lopezdiaz@gmail.com. Este trabajo forma parte del Proyecto FONDECYT de Iniciación $\mathrm{N}^{\circ}$ 11150423: "Hacia la articulación de un sistema de medios de tutela por responsabilidad precontractual en el Código Civil Chileno", del que la autora es investigadora responsable.

1 En la doctrina comparada, De Verda (2009) pp. 29-85, y, en la nacional, Barrientos (2011) pp. 363-385 y OVIEDO (2010) pp. 241-259, autor este último que también ha profundizado en sus requisitos OviEDo (2016) pp. 129-169.

2 Larroucau (2015) pp. 259-306 y Oviedo (2016) pp. 160-161.
} 
ticularmente a la acción de rebaja del precio, analizando su naturaleza jurídica ${ }^{3}$, la concurrencia con la indemnización por infracción del deber precontractual de informar el vicio redhibitorio que afectaba a la cosa vendida ${ }^{4}$ y su método de cálculo ${ }^{5}$, abordando incluso la autonomía de dicha pretensión indemnizatoria, formulando premisas sobre las cuales puede erigirse y cotejándola con aquella derivada del incumplimiento contractual ${ }^{6}$.

No ha ocurrido lo mismo tratándose de la acción redhibitoria contemplada en los artículos 1857 y siguientes del Código Civil, pues no se ha analizado detenidamente su naturaleza jurídica ni se ha intentado determinar el efecto derivado de su interposición, en circunstancias que se trata de un tópico de gran relevancia práctica, toda vez que podría acarrear la resolución del contrato, su rescisión o la nulidad relativa, dependiendo de cuál sea la doctrina a la que se adhiera y, en cualquiera de esas hipótesis, si bien el plazo de prescripción sería aquel estipulado en el artículo 1866, las consecuencias jurídicas de su interposición serían diversas.

La discusión se ha suscitado a partir de la utilización de las expresiones "rescinda" y “rescisión” empleadas por los artículos 1857 y 1860 a propósito de la compraventa, pues algunos autores han entendido que sería equivalente a la nulidad relativa ${ }^{7}$, rescisión por lesión enorme ${ }^{8}$ o a la resolución por incumplimiento ${ }^{9}$, debate que también puede extrapolarse a la acción redhibitoria prevista en los contratos de arrendamiento y mutuo, toda vez que los artículos 1932 y 2203, también emplean, respectivamente, tales vocablos.

Lo cierto es que, como se demostrará en esta investigación, se trata de una expresión cuyo sentido y alcance no resulta claro, de modo que requiere una precisión dogmática que defina si, efectivamente, es sinónimo de nulidad relativa, existe entre ellas una relación de género a especie o son nociones contrapuestas. Esta necesidad se advierte especialmente en nuestro Código Civil, pues, como referiremos más adelante, tampoco la ha utilizado en un sentido unívoco, sino que, en algunos casos, la concibe en su sentido dogmático puro, en ocasiones la equipara a la nulidad y, en otros supuestos, la asimila a la resolución ${ }^{10}$.

Podría pensarse que nuestro intento es inoficioso, dado que en la última década la doctrina comparada ha subsumido a las acciones edilicias en la noción de "falta de conformidad" formulada por el movimiento europeo de modernización del derecho de obligaciones y contratos ${ }^{11}$ e incluso, nuestra dogmática, ha sugerido acuñarla para simplificar el

3 La doctrina mayoritaria ha sostenido que se trata de una acción de garantía. Así, BerCovitz (1969) pp. 802805, Morales (1991) p. 960, Barros (2006) p. 983 y Oviedo (2014a) pp. 235-236.

4 Morales (1980), pp. 616-617, De Verda (2009) pp. 305-310, Guzmán (2007) pp. 97-119, Ferrante (2012) pp. 88-98, Oviedo (2014a) pp. 237-274 y López (2016) pp. 677-678.

5 Ferrante (2014) pp. 9-49 y Prado (2015) pp. 617-649.

6 Morales (1991) pp. 961-962, Guzmán (2007) pp. 103-116, De Verda (2009) pp. 210-213, Díez-Picazo (2010) pp. 139-140, Luminoso (2009) p. 293, De la Maza (2010) p. 457, nota 10, Oviedo (2014a) pp. 237274 y LOPEZ (2016) pp. 659-683

7 GUZMÁN (2007) pp. 99-101 y BARAONA (2008) pp. 665 y 669.

8 Santos (1973) pp. 78-79, Llácer (1992) pp. 121-122 y 133-134, De Verda (2009) pp. 299-301, Morales (2012) p. 17 y García (2014) p. 453.

9 Véase principalmente a Díez-Picazo (2010) p. 139 y entre nosotros a Alessandri (2003), Vol. I. p. 218.

10 Ver Sección 1.A.v.

11 Fenoy (2006), Morales (2006) pp. 93-144 y Vaquer (2011) pp. 5-39. 
sistema de protección del comprador y evitar una innecesaria e injustificada fragmentación del incumplimiento por falta de adecuación material ${ }^{12}$. Pero, mientras ello no ocurra, o no se modifique nuestro Código Civil en tal sentido, resulta necesario precisar la naturaleza jurídica de la acción redhibitoria, pues su falta de determinación genera inseguridad al acreedor, ya que este desconoce las consecuencias jurídicas derivadas de su interposición y la solución de los concursos de acciones que ella pudiera acarrear, desvaneciéndose, por consiguiente, su protección ante el incumplimiento del deudor. De allí que podamos sostener que esta indeterminación ha impedido articular con exactitud el sistema de tutela del comprador en el Derecho civil chileno y que se trata de una tarea inconclusa que requiere una solución definitiva.

Y es que si se aboga por su naturaleza rescisoria o resolutoria, la ineficacia operará hacia el futuro, traduciéndose en la liquidación económica del contrato a través de las restituciones pertinentes ${ }^{13}$, a diferencia de lo que ocurriría si se postula su naturaleza anulatoria, toda vez que, en tal supuesto, la ineficacia tiene indiscutiblemente un efecto retroactivo. Tal diferencia acarrea que la extensión del daño indemnizable varíe en uno u otro caso, sea que la pretensión indemnizatoria se ejerza en forma complementaria a las acciones edilicias o independientemente de aquellas, dado que el efecto retroactivo determina la indemnización del interés negativo o de la confianza; en cambio, el efecto restitutorio, el resarcimiento del interés positivo o de cumplimiento.

Por otra parte, las distintas teorías sobre la naturaleza jurídica de la acción redhibitoria complejizan el sistema de protección del acreedor, dado que, según el caso, estaremos ante una acción precontractual (anulatoria o rescisoria) o contractual (resolutoria por incumplimiento), constatación que acarrea dos importantes consecuencias. En primer lugar, se trataría de una acción prevista para supuestos diversos a los vicios redhibitorios, pero que, con ocasión de estos, el legislador habría replicado, en principio, con un plazo de prescripción menor. En efecto, el plazo de la anulatoria es de 4 años contados en la forma prevista en el artículo 1691 del Código Civil y el de la resolutoria es de 5 años desde que la obligación se hizo exigible, según se desprende del artículo 2515 de dicho cuerpo normativo; en cambio, el plazo de la acción redhibitoria, cualquiera fuera la naturaleza jurídica que se le atribuyera, sería el previsto en el artículo 1866, esto es, 6 meses para los bienes muebles y 1 año para los inmuebles, facultándose a las partes para ampliar o restringir estos plazos. En segundo lugar, si sostenemos que se trata de una acción resolutoria o de nulidad por error, existiría un concurso entre ellas y la redhibitoria, que, independientemente que sea horizontal o vertical ${ }^{14}$, podrá solucionarse a través del principio de especialidad, privando al acreedor de las acciones generales por incumplimiento, o bien reconociéndole la opción entre la redhibitoria -cualquiera sea su naturaleza jurídica-y aquellas ${ }^{15}$.

\footnotetext{
12 De la Maza (2015) pp. 98-99 y De la Maza (2014) pp. 149-157.

13 En la doctrina nacional Pizarro (2012) pp. 457-460, Contardo (2015) pp. 317-334, Alcalde (2015) pp. 591-594 y MEjÍAs (2016) pp. 271-322.

14 A propósito de tales concursos Caprile (2008) pp. 574-582 y De la MAZA (2014) pp. 126-149.

15 Sobre tal discusión De la Maza (2006) pp. 155-158, Caprile (2008) pp. 575-593, Baraona (2008) pp. 664-665 y Figueroa (2011) pp. 111-120.
} 
Dicho concurso no se advierte si postulamos que se trata de una acción rescisoria por lesión enorme, toda vez que, atendido el principio de conservación de los actos jurídicos, solo puede demandarse la rescisión como efecto derivado de ella en los supuestos expresamente previstos por el legislador (compraventa y permuta de bienes inmuebles [arts. 1888-1889-1891 y 1900], partición de bienes [art. 1348] y aceptación de una asignación hereditaria [art. 1234] $)^{16}$, de modo que no existiría concurso, pues no se advierte en nuestro Código una acción rescisoria general por lesión enorme, sino una especial prevista para tales casos. Distinto es que pueda ensayarse una noción amplia de lesión enorme, que se proyecte más allá de las hipótesis reguladas en el Código Civil y sostenerse que, salvo el supuesto de la aceptación de la asignación hereditaria, el acreedor tiene la posibilidad de adaptar el contrato a través de la rebaja de la prestación excesiva o el suplemento del valor no enterado ${ }^{17}$. Un fenómeno similar se advierte tratándose de la rescisión stricto sensu, dado que se encuentra acotada a ciertos supuestos. Volveremos sobre este punto en el último apartado de este artículo.

La interrogante que debe resolverse, entonces, es si se justifica replicar, en el supuesto de vicios redhibitorios, la acción resolutoria, anulatoria o rescisoria por lesión enorme o stricto sensu, teniendo en especial consideración el supuesto de hecho de tales vicios, las consecuencias adversas que ellos generan para el acreedor, la finalidad específica que persiguió el legislador al establecer la acción redhibitoria y la necesidad de optimizar el sistema de protección del comprador y, en términos generales, del acreedor que pretenda interponerla, otorgándole la posibilidad de escoger entre el mayor número de acciones posible.

Para alcanzar tal propósito se expondrán las teorías que tradicionalmente ha esgrimido la dogmática nacional para explicar la naturaleza jurídica de la acción redhibitoria, distinguiendo aquella mayoritaria y prevalente que sustenta el carácter resolutorio de dicha acción y la tesis que la concibe como anulatoria, a partir del tenor literal de los preceptos que la recogen y la historia fidedigna de su establecimiento en el Código Civil, agregando una tercera opción, que a la fecha no ha sido explorada por la civilística chilena, cual es, sostener que es rescisoria por lesión enorme o stricto sensu en los casos que ella no tiene lugar (1). Posteriormente, se analizará la incidencia de la naturaleza jurídica de dicha acción en el sistema de protección del comprador, contraponiendo dogmáticamente los efectos derivados de tales teorías (2). Examinados tales tópicos, se formularán las conclusiones.

\section{TEORÍAS EN TORNO A LA NATURALEZA DE LA ACCIÓN REDHIBITORIA PREVISTA EN LOS ARTÍCULOS 1857 Y 1860 DEL CÓDIGO CIVIL}

La historia fidedigna del establecimiento de los artículos 1857 y 1860 evidencia que el carácter rescisorio de la acción redhibitoria fue introducido por don Andrés Bello, en el caso del primero, en Proyecto de 1853 del Código Civil y, tratándose del segundo,

\footnotetext{
${ }_{16} \mathrm{Y}$ es que no se puede dejar sin efecto un acto jurídico sin que exista causal legal que lo permita, como lo prescribe el art. 1545 del Código Civil. De allí que, en otro sitio, se postule que el efecto de admitir una noción amplia de lesión enorme es la rebaja de la prestación excesiva (véase López (2015a) pp. 720-723).

17 López (2015a) pp. 720-723 y López (2017) pp. 657-708.
} 
al momento de realizar la corrección final de la versión definitiva, pues en los Proyectos precedentes esta tenía un carácter resolutorio. Así lo revelan el artículo 37 del Proyecto de 1841-1845 y el artículo 360 del Proyecto de 1846-1847 que preexistieron al artículo 2039 del Proyecto de 1853, que utilizaban la expresión "resuelva" en vez de "rescinda" y que constituye el antecedente del actual artículo 1857. Otro tanto se advierte en el artículo 39 del Proyecto de 1841-1845, el artículo 362 del Proyecto de 1846-1847 y el artículo 2041 del Proyecto de 1853 y del Proyecto Inédito, que emplean la voz "resolución” y que fue enmendada por "rescisión" en la corrección final de la versión definitiva del actual Código $\mathrm{Civil}^{18}$. Por consiguiente, no debería existir discusión sobre la naturaleza jurídica de la acción redhibitoria, pues, como lo indica el inciso primero del artículo 19 del Código Civil, "cuando el sentido de la ley es claro, no se desatenderá su tenor literal, a pretexto de consultar su espíritu”.

Sin embargo, desde antiguo se ha criticado el reemplazo de tales expresiones, indicando que el legislador incurrió en un error, dado que contempló una forma de ineficacia civil que no se aviene con el supuesto de los vicios redhibitorios ni con la doctrina romana, en la que ellos encuentran su origen ${ }^{19}$. Con todo, en la última década, se ha sugerido que la voz "rescisión" es la adecuada, a partir de la revisión de los Proyectos que antecedieron al de 1853 y recurriendo a algunos argumentos dogmáticos que, a nuestro juicio, no son enteramente concluyentes ${ }^{20}$. Nada se ha dicho, en cambio, de una eventual naturaleza rescisoria stricto sensu o derivada de la lesión enorme, en circunstancias que tal postura podría ser una alternativa, dogmáticamente más adecuada que las anteriores, como intentaremos demostrar en esta investigación.

Podría pensarse que se trata de una discusión relativamente simple que se traduce en contraponer distintas sanciones de ineficacia o recurrir al elemento gramatical o histórico de interpretación de la ley, pero en realidad es más compleja. En efecto, de un lado supone precisar si la acción redhibitoria se vincula con el incumplimiento de un contrato válidamente formado, un vicio constitutivo que impide que un negocio se forme válidamente o el desequilibrio prestacional derivado del desperfecto de la cosa. Y de otro, establecer si las acciones de resolución, nulidad o rescisión confluyen cuando se verifica la existencia de vicios redhibitorios o una de ellas desplaza a la otra. A ello se agrega que los autores que abogan por dichas teorías argumentan en términos muy generales su planteamiento, no formulan críticas que desbaraten las premisas en que se cimienta la tesis contraria ni sistematizan un constructo teórico que permita inclinarse por estas o, en definitiva, desestimarlas.

No obstante ello, intentaremos extraer y sistematizar los argumentos sobre los cuales se sustenta la naturaleza resolutoria, anulatoria o rescisoria por lesión enorme de la acción redhibitoria, con el propósito de someterlas a un examen crítico y arribar a una conclusión acabada y debidamente fundada. Para alcanzar este propósito, seguiremos el orden en que han sido formuladas en la dogmática nacional y, a medida que vayamos enunciando tales premisas, nos pronunciaremos sobre su pertinencia o improcedencia, adelantando, en par-

18 GuZMÁn (2007) pp. 99-100 y BaraOna (2008) p. 665.

19 Alessandri (1918) p. 304.

20 Guzmán (2007) pp. 100 y 110-111, Baraona (2008) pp. 661-662 y 665-668 y Alcalde (2010) p. 74. 
te, nuestro planteamiento para abordarlo decidida y sistemáticamente al final de esta investigación.

\section{a) LA NATURALEZA RESOLUTORIA DE LA ACCIÓN REDHIBITORIA: LA TESIS TRADICIONAL Y PREVALENTE}

Un examen de la dogmática y jurisprudencia nacional revela que la tesis que ha prevalecido desde antiguo para explicar la naturaleza jurídica de la acción redhibitoria es aquella que postula su carácter resolutorio, prescindiendo del tenor literal de los artículos 1857 y 1860. En efecto, se ha sostenido que, aun cuando el legislador emplee en tales preceptos la expresión "rescinda" y "rescindir", respectivamente, habría otorgado al comprador una acción resolutoria con un plazo especialísimo de prescripción de seis meses o un año, según se trate de un mueble o inmueble, que permitiría aniquilar el contrato por el vicio redhibitorio del que adolece la cosa.

El principal exponente de esta tesis es AlESSANDRI, quien en las diversas ediciones de su obra "De la compraventa y de la promesa de venta", sostiene que el legislador ha incurrido en un error al utilizar tales expresiones y hubiera sido preferible que se refiriera a la resolución, como lo hacía en el Proyecto de 1853. En tal sentido precisa que, en este caso, el derecho del comprador deriva de la "inejecución de la obligación del vendedor" y que ella acarrea la resolución, pero no la rescisión del contrato", agregando que esta última supone la existencia de un vicio que afecta su subsistencia y que aquí no existe ${ }^{21}$.

Dicho planteamiento ha sido seguido por la mayoría de la doctrina y jurisprudencia nacional ${ }^{22}$, contraviniéndose expresamente el tenor literal de los artículos 1857 y 1860 del Código Civil. Es muy probable que este fenómeno se explique por la influencia que tuvieron los autores franceses en la civilística nacional en materia de obligaciones y contratos, pero, a diferencia de nuestro Código que emplea la expresión "rescisión", el Code utiliza la voz "resolución" en el artículo 1641-2, de modo que resulta razonable que la doctrina gala abogue por la naturaleza resolutoria de la acción redhibitoria, pero incomprensible que nuestra dogmática se incline por ella.

Si bien no se han sistematizado los argumentos que abogan por esta postura, un análisis de la resolución por inejecución y un examen de los autores y sentencias que la sustentan permiten deducir que esta teoría se erige sobre las siguientes premisas o argumentos: i) La acción redhibitoria es un medio de tutela frente a un cumplimiento imperfecto, ii) La exigencia de gravedad de los vicios ocultos determinaría una hipótesis de resolución, iii) El derecho romano concibió la acción redhibitoria como resolutoria, doctrina que fue seguida por otros Códigos, iv) La interpretación armónica de determinados preceptos contenidos en el párrafo 8 del Título 23 del Libro IV del Código Civil y v) La errada y equívoca calificación como rescisorias de acciones que son resolutorias en otras disposiciones del Código Civil.

\footnotetext{
21 Alessandri (1918) p. 304, afirmación que mantiene en Alessandri (2003), Vol. I, p. 218.

22 Barcia (2007) p. 83, Díez (2009) p. 258 y Troncoso (2014) p. 126.
} 


\section{i. La acción redhibitoria es un medio de tutela frente a un cumplimiento imperfecto}

Tradicionalmente la doctrina nacional, a partir de lo preceptuado en los artículos 1824 y 1837 del Código Civil, ha concebido a las acciones edilicias como acciones de incumplimiento que el comprador puede ejercer para hacer efectiva la obligación de saneamiento de los vicios redhibitorios, prevista en este último precepto ${ }^{23}$. Sin embargo, esta aseveración no parece ser tan correcta, pues como acertadamente destaca el profesor Jorge Baraon ${ }^{24}$, si bien la obligación que el legislador describe en tales preceptos parece apoyarse en la obligación que tiene el vendedor de entregar lo que reza el contrato, su explicación más técnica se encontraría en el deber que tiene el vendedor de aceptar la rescisión del contrato o la reducción del precio, según proceda, cuando el comprador intente alguna de tales acciones para exigir el saneamiento de los vicios redhibitorios.

En otras palabras, y aunque el autor no utilice expresamente esa denominación, se trata de acciones de garantía por vicios y falta de cualidad de la cosa, pero no de incumplimiento, pues estas forman parte de la obligación de saneamiento, expresión que jurídicamente se ha definido como "el acto de afianzar o asegurar el reparo o satisfacción del daño que puede sobrevenir" y que, en el lenguaje cotidiano, viene a significar "reparar, remediar o hacer que una situación mejore" 25 . En efecto, dichas acciones operan como una garantía que asegura la satisfacción del acreedor frente a la existencia de los vicios de la cosa, lo que permite constatar que, en nuestro sistema, el deudor no está obligado a entregar la cosa libre de defectos ni garantizar que ella será útil, sino a sanearla, como se desprende de los referidos artículos 1824 y 1837.

Tal naturaleza jurídica se les ha otorgado desde antiguo en la doctrina comparada y, en los últimos años, en la civilística nacional, toda vez que la acción redhibitoria y la quanti minoris tienen por propósito restablecer el equilibrio contractual perdido, mediante la restitución del valor de la prestación, en todo o en parte, respectivamente ${ }^{26}$. De hecho, ya en el año 1980, el profesor Antonio Manuel Morales Moreno precisaba que se trataba de "acciones de responsabilidad especial" ${ }^{27}$, indicando que se diferencian de las acciones de incumplimiento en su origen histórico, regulación, supuesto de hecho, plazo de prescripción y efectos, agregando, recientemente, que la redhibitoria se diferencia de la resolutoria en que la primera se inserta en el sistema de remedios del saneamiento, en tanto, la segunda, en el de incumplimiento ${ }^{28}$.

La única excepción se configuraría en aquel supuesto que las partes pactaran que la obligación de entregar comprende la ausencia de vicios redhibitorios, lo que es perfectamente posible si se considera que el saneamiento de la evicción constituye un elemento de la naturaleza de la compraventa, de modo que los contratantes pueden alterarlo, suprimirlo o modificarlo, no obstante lo cual, el vendedor no podrá eximirse de tal obligación

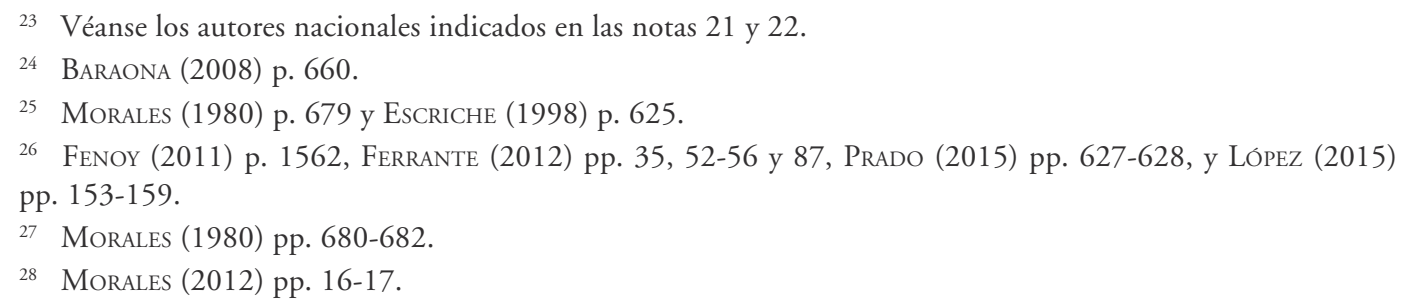


si ocultó dolosamente el defecto de la cosa, como lo dispone el artículo 1859 del Código Civil. Por consiguiente, si la cosa adolece de tales vicios, solo en este caso, estaremos ante la inejecución de la obligación de entrega, lo que faculta al comprador para recurrir a los medios de tutela contractuales, pudiendo configurarse un concurso entre ellos y las acciones edilicias $^{29}$.

Distinto es que, en el último tiempo, se haya intentado reconducir los vicios redhibitorios a las acciones generales de incumplimiento, recurriendo a la noción de falta de conformidad, que las subsume, a partir de la noción amplia de incumplimiento que consagran los instrumentos europeos de modernización del derecho de obligaciones y contratos ${ }^{30}$ y que, la jurisprudencia nacional haya acogido, en ocasiones, la resolución por incumplimiento o la indemnización de daños, a partir de la noción de aliud pro alio ${ }^{31}$, admitiendo el derecho de opción del acreedor entre las acciones edilicias y aquellas generales por incumplimiento contractual.

\section{ii. La exigencia de gravedad de los vicios ocultos determinaría una hipótesis de resolución}

Esta segunda premisa sobre la cual podría sustentarse la naturaleza resolutoria de la acción redhibitoria no se ha formulado aún, pero fluye lógicamente si se vincula el incumplimiento resolutorio al carácter grave de la inejecución que, tratándose de los vicios redhibitorios, es indubitada. Así se desprende del numeral 2 del artículo 1858 del Código Civil que exige que los vicios sean tales que por ellos "la cosa vendida no sirva para su uso natural, o solo sirva imperfectamente, de manera que sea de presumir que conociéndolos el comprador no la hubiera comprado o la hubiera comprado a mucho menos precio".

$\mathrm{Y}$ es que, independientemente que la doctrina nacional reciente abogue por superar la noción material de vicios redhibitorios contenida en tal precepto y sugiera acuñar una funcional -entendiendo por tal cualquier defecto que haga la cosa impropia para el concreto uso que motivó su adquisición o lo dificulte ${ }^{32}-$, actualmente no se discute que si éstos son graves -lo que dependerá de la noción que se adopte ${ }^{33}-$, el comprador pueda intentar la acción redhibitoria para desvincularse del contrato. Pues bien, tal gravedad podría asociarse a la esencialidad del incumplimiento resolutorio, pues claramente el acreedor ve frustrado el interés que tuvo en vista al momento de celebrar el contrato o bien dicha ineje-

\footnotetext{
29 Si bien la Corte Suprema no ha tenido oportunidad de pronunciarse sobre la admisibilidad de la opción del acreedor entre tales acciones, todo parecería indicar, que, de hacerlo, se inclinaría por desestimarla, pues en aquellos casos que las partes han convenido que la cosa que se entrega no debe estar gravada con derechos en favor de terceros, la ha rechazado, invocando el principio de especialidad para reconducir al comprador al régimen general de la evicción, razonamiento que perfectamente podría replicar en el supuesto que venimos comentando. Un contundente análisis de esta tendencia jurisprudencial en De LA MAZA (2012a) pp. 99-113.

30 Morales (2006) pp. 93-144, Vaquer (2011) pp. 5-39 y De la Maza (2015) pp. 79-100.

31 López (2014a) pp. 605-624 y Barrientos (2015) pp. 135-154.

32 A tal efecto se ha invocado la noción de vicio que acoge la jurisprudencia, la interpretación de dicho precepto a partir del artículo 1863 que permitiría entender, como ausencia de cualidades, los vicios que naturalmente no lo son y la necesidad de satisfacer el interés del acreedor (BARRIENTOS (2011) pp. 373-374 y Oviedo (2010) p. 262).

33 Sobre este tópico véase Oviedo (2016) pp. 138-143.
} 
cución puede determinar la pérdida de la confianza en el futuro cumplimiento de su deudor $^{34}$. De hecho, un examen de la jurisprudencia nacional revela que se ha calificado como grave el vicio que impide o reduce el uso normal de la cosa o aquel que se ha convenido, esto es, la hace inepta o inidónea ${ }^{35}$, supuesto que encaja perfectamente con ambas hipótesis de incumplimiento resolutorio.

Sin embargo, no tendría mucho sentido que el legislador restringiera el plazo de prescripción de la acción resolutoria tratándose de los vicios redhibitorios y le otorgara al comprador un plazo de 6 meses para los muebles y un año para los inmuebles en el artículo 1866, en comparación al plazo de 5 años que resulta aplicable a partir del artículo 2515 del Código Civil. Más aún si, como ha admitido la doctrina reciente, no hay impedimento para que el comprador opte directamente por la acción resolutoria si acredita la gravedad o esencialidad del incumplimiento, pues no existiría un orden de prelación entre las acciones edilicias y las acciones por incumplimiento, admitiéndose el concurso entre ellas ${ }^{36}$.

\section{iii. En derecho romano concibió la acción redhibitoria como resolutoria, doctrina que fue seguida por otros Códigos}

Sabido es que la acción redhibitoria surge en el derecho romano como una creación de los ediles curules y que su finalidad fue otorgar un sistema especial de protección al comprador frente a los vicios redhibitorios, permitiéndole recuperar el precio pagado, devolviendo la cosa comprada. Esta figura se mantuvo en las Partidas y fue recogida por el Code que empleó expresamente la voz "resolución" en el artículo 1642-1 para referirse al efecto de la acción redhibitoria ${ }^{37}$, modelo que fue seguido, entre otros, por los artículos 1492 y 1493 del Codice, 1521 del Código Civil Brasileño de 2002 y 1057 del Código Civil y Comercial argentino de 2014.

Con todo, que el derecho romano y otros Códigos Civiles la concibieran como resolutoria no constituye un argumento concluyente para sostener que esa es su naturaleza jurídica en nuestro Código, toda vez que, la primera constatación tiene una explicación dogmática y, la segunda, una justificación normativa que no pueden extrapolarse a los artículos 1857 y 1860 . Y es que Roma no conoció, hasta ese entonces, una acción resolutoria en el contrato de compraventa, de modo que el efecto resolutorio derivado de la acción redhibitoria se justificaba plenamente, pues, salvo el pacto de la Lex Commissoria por no pago del precio, el contratante cumplidor no tenía otro mecanismo para desvincularse del incumplidor ${ }^{38}$. No es el caso del Código Civil chileno que contempla la resolución por incumplimiento a propósito de los contratos bilaterales en el artículo 1489 y que ha permitido sustentar la existencia de la facultad resolutoria del acreedor en dicho cuerpo normativo.

\footnotetext{
34 En la doctrina nacional véase MejíAs (2011) pp. 206-278.

35 Un completo análisis jurisprudencial en Oviedo (2010) pp. 244-251.

36 Caprile (2008) pp. 579-582, Baraona (2008) pp. 668-669, Figueroa (2011) pp. 118-120, De la Maza (2014) pp. 141-145. La Corte Suprema, en cambio, no ha tenido ocasión de pronunciarse sobre la opción del acreedor frente a dicho concurso de acciones. Véase la nota 29.

37 Sobre su origen y recepción en la Codificación Morales (1980) pp. 594-623 y Oviedo (2014b) pp. 202-229.

38 D’Ors (1997) pp. 558-559 y GuZMán (2013) pp. 160-161.
} 
Por otro lado, si bien existen Códigos que conciben la acción redhibitoria como resolutoria, entre los que destacan los referidos precedentemente, otros se apartaron de ese modelo como el chileno y el español, cuyos artículos 1860 y 1486 inciso segundo, respectivamente, emplean la voz "rescisión". Lo cierto es que, contrariamente a lo que pudiera pensarse, la utilización de una misma expresión ha determinado, por una parte, que la mayoría de la doctrina española se incline por sustentar su naturaleza rescisoria ${ }^{39} \mathrm{y}$, por otra, que la tesis prevalente en la dogmática nacional sea la que le atribuye un carácter resolutorio, en circunstancias que se trata de una institución con idénticas raíces, contenida en Códigos que siguieron un mismo modelo ${ }^{40}$. Tal divergencia justifica, como la haremos al abordar la tesis que postula la naturaleza rescisoria de la acción redhibitoria, volver sobre esta discusión para contraponer estas opiniones e intentar arribar a una conclusión coherente y definitiva, que explique por qué nuestro legislador prefirió emplear, en definitiva, la expresión "rescinda" y "rescisión" en los artículos 1857 y 1860 y no la voz "resolución".

\section{iv. La interpretación armónica de determinados preceptos contenidos en el Libro IV del Código}

El cuarto argumento que se ha aducido para justificar la naturaleza resolutoria de la acción redhibitoria ha sido formulado por algunas sentencias de nuestros tribunales y consiste en sostener que el sentido y alcance de los artículos 1857, 1859, 1860, 1861, 1862, 1865, 1867, 1868, 1869 y 1870, ubicados en el párrafo 8 del Título 23 del Libro IV del Código Civil a propósito del saneamiento por vicios redhibitorios, permiten arribar a tal conclusión.

En efecto, la Corte Suprema, al menos en cuatro sentencias pronunciadas entre los años 2005 y 2011 ha sustentado este planteamiento. Se trata de Cecinas La Preferida con Comercial Salinak Ltda.(2005), en que acogió la resolutoria por la entrega de una cosa diversa a la pactada, Larzabal Beraza con Sociedad Inmobiliaria Talasia Ltda. (2008), Servicios de Impresión J.A. Amenábar Ltda. con Fuentes Riquelme (2008), agf Allianz Compañía de Seguros Generales S.A. con Le Torneau Inc. (2010) y Toro Mancilla con Banco Santander Chile (2011), en los que admitió la procedencia autónoma de la indemnización prevista en el artículo 1861 por infracción del deber precontractual de informar los vicios redhibitorios de la cosa, pronunciándose sobre la naturaleza jurídica de la acción redhibitoria y precisando que "una interpretación armónica e integral de tales disposiciones lleva a entender que la acción resolutoria es propiamente redhibitoria” ${ }^{\text {" }}$.

Sin embargo, un detenido análisis revela que los referidos artículos, ni en forma aislada, ni interpretados lógica y armónicamente permiten calificar de resolutoria dicha acción, pues solo regulan las acciones edilicias y la pretensión indemnizatoria por vicios redhibitorios, utilizando la expresión "rescisión" para referirse a la redhibitoria. Y es que si bien

\footnotetext{
39 Véase los autores españoles indicados en la nota 8 y 42.

40 Manifestando su asombro por este tratamiento tan disímil Caprile (2008) p. 584.

41 Cecinas La Preferida con Comercial Salinak Ltda. (2005) considerando 5ª Larzabal Beraza con Sociedad

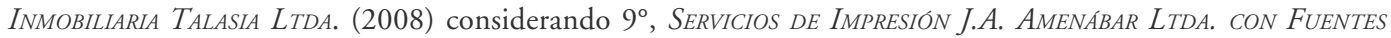
RiQuelme (2008), considerando $3^{\circ}$ y $4^{\circ}$, AGF ALlianz CompañIa DE SEGURos GENERALES S.A. con LE TORNEAU INC. (2010), considerando $11^{\circ}$, TORO MANCILLA CON BANCO SANTANDER CHILE (2011), considerando $9^{\circ}$ y $10^{\circ}$.
} 
no lo señalan expresamente, las sentencias pronunciadas en tales casos parecen seguir la doctrina mayoritaria que desatiende el tenor literal de los artículos 1857 y 1860 del Código Civil, dado que no admiten, bajo ningún supuesto, que el legislador hubiera empleado correctamente tal expresión, de modo que constituyen una reiteración de las premisas que hemos venido controvirtiendo en este apartado que, por lo mismo, no invoca ni agrega argumentos dogmáticos que permita sustentar el carácter resolutorio de la acción redhibitoria.

\section{v. La errada y equívoca calificación como rescisorias de acciones que son resolutorias en otras disposiciones del Código Civil}

El último argumento que podría esgrimirse para sustentar la naturaleza resolutoria de la acción redhibitoria es que el legislador, en algunas ocasiones, ha calificado erróneamente acciones resolutorias como rescisorias. Tal es el caso de la acción regulada en el artículo 1590 a propósito del cumplimiento imperfecto de la obligación de dar una especie o cuerpo cierto y aquella prevista en el artículo 2271 relativa a la renta vitalicia si los contratantes han pactado su procedencia en el caso que no se pague la pensión, pues, en ambas hipótesis, faculta al acreedor para solicitar la "rescisión" del contrato, en circunstancias que ha existido incumplimiento, de modo que se trata de acciones resolutorias.

Lo cierto es que, más allá de la denominación empleada por el legislador en un caso particular, debe determinarse la naturaleza jurídica de las instituciones consagradas en nuestro Código acudiendo a consideraciones dogmáticas que permitan establecerla. Más aun tratándose de expresiones que no utiliza unívocamente, como ocurre con la voz "rescisión". Y es que, como lo anunciamos al principio, no solo la confunde con la resolución, sino que, en algunos supuestos, la equipara a la nulidad relativa y, en otros, la utiliza en su sentido técnico. La sinonimia con la primera se advierte tratándose de los actos ejecutados respecto de bienes familiares sin la autorización del cónyuge no propietario (art. 143), en el Título XX del Libro IV relativo a la nulidad (arts. 1686 y 1691), a propósito de la renuncia de la mujer casada en sociedad conyugal a los gananciales (art. 1782) y en la transacción (arts. 2456, 2459 y 2460). En cambio, su correcta utilización se aprecia con ocasión del decreto de posesión definitiva del desaparecido (arts. 93 y 94), en la lesión enorme a propósito de la aceptación de una asignación hereditaria (art. 1234), partición de bienes (arts. 1348 y 1351-1353), compraventa de inmuebles (arts. 1853-1854 y 1888-1898), permuta de inmuebles (art. 1900), en las enajenaciones de bienes del difunto hechas por los herederos (1384) y en los modos de extinguir (art. $1567 \mathrm{~N}^{\circ} 8$ ).

Con todo, en los supuestos de los artículos 1590 y 2271 se advierte claramente que ha querido referirse a la resolución y no a la rescisión, dado que dogmáticamente resulta indiscutido que la primera es una forma de ineficacia intrínseca (esto es, propia del vínculo jurídico) y sobrevenida, pues deriva de la facultad que se otorga a uno o ambos contratantes para dejar sin efecto el contrato en aquellos casos en que el incumplimiento es grave o esencial, sea porque convencionalmente se le dio ese carácter, así se manifiesta en las consecuencias que el incumplimiento produce en el propósito práctico perseguido por el acreedor o acarrea la pérdida de confianza en el cumplimiento futuro del deudor. En cambio, la rescisión es una forma de ineficacia extrínseca y funcional, cuya causa es originaria, pues procede respecto de actos válidamente celebrados que producen un perjuicio que se estima 
injusto y que tiene por fundamento la ruptura del sinalagma contractual. A ello se agrega que la rescisión solo procede en virtud de una norma que expresamente la contemple y por regla general tiene un carácter subsidiario, a diferencia de la resolución que tiene un carácter principal y en que las partes, en virtud de la autonomía de la voluntad, podrían pactar el ejercicio de la facultad resolutoria reconocida por la ley, a través de una cláusula resolutoria ${ }^{42}$.

Por consiguiente, el argumento de la errónea calificación de la acción redhibitoria como rescisoria se diluye y debe descartarse para sustentar su naturaleza resolutoria, toda vez que estamos ante un caso en que resulta aplicable el principio de irrelevancia del nomen iuris no respecto de la calificación que le han otorgado las partes a un determinado instituto, sino de aquella que ha realizado el legislador, toda vez que, de lo que hasta aquí hemos venido sosteniendo, resulta evidente que dicha acción no es resolutoria. Más aún si, como acertadamente ha indicado Morales Moreno, la función de la acción redhibitoria se aproxima a la anulación del contrato por error o a la rescisión por lesión enorme, toda vez que ofrecen al contratante la posibilidad de desvincularse del contrato sin los medios de tutela orientados a la satisfacción del interés positivo ${ }^{43}$.

\section{b). La NATURALEZA ANULATORIA DE LA ACCIÓN REDHIBITORIA: LA TESIS RECIENTE Y EMERGENTE}

La segunda teoría que intenta explicar la naturaleza jurídica de la acción redhibitoria fue formulada principalmente por la doctrina francesa y española y postula que podría intentarla el comprador que padeció un error sustancial, esto es, una falsa representación de la sustancia o calidad esencial del objeto sobre el que versa el acto o contrato, pues supuso que la cosa que pretendía adquirir carecía de imperfecciones graves, ocultas y preexistentes. Según este razonamiento, las cosas se compran para destinarlas a un uso adecuado, de modo que, si presentan defectos ocultos que lo hacen imposible o lo disminuyen ostensiblemente, ha existido un error (porque ellos no se advirtieron), cuyo carácter sustancial faculta al comprador para desvincularse del contrato, equiparándose así la noción de error vicio con vicio redhibitorio ${ }^{44}$.

Claro está que la nulidad relativa es una forma de ineficacia civil que tiene lugar en aquellos casos en que se han omitido los requisitos de validez del acto o contrato que el legislador exige, atendida la calidad de las personas intervinientes, y que esta resulta procedente, entre otras causales, cuando existe error sustancial. De otro lado, es indiscutido que la acción redhibitoria difiere conceptual y funcionalmente de la acción de nulidad, dado que la primera exige que el comprador adquiera una cosa con una sustancia diversa o desprovista de las cualidades esenciales que creía que ella tenía, en tanto, la segunda, que

\footnotetext{
42 Espinar (1969) pp. 141-142, Martín (1995) pp. 197, 212-213, 218-223 y 229, Betti (2000) pp. 431-433 y Alberruche (2010) pp. 166-167.

43 Morales (2012) p. 17.

44 Mucius (1906) pp. 616-617, 624, 627 y 685, Capitant (1927) pp. 232-233, Célice (1920) p. 217 y BerCovitz (1969) pp. 780-799.
} 
la cosa adolezca de vicios redhibitorios, sin que se requiera que dicho consentimiento esté viciado.

Por consiguiente, cabe preguntarse si, efectivamente, puede equipararse el vicio redhibitorio al error sustancial, más aún si tal argumento ha sido recogido por algunos autores nacionales que han sustentado la naturaleza anulatoria de la acción redhibitoria ${ }^{45}$. Con todo, no nos abocaremos exclusivamente a su análisis (i), sino que examinaremos otros más específicos que han sido formulados para fortalecerlo, cuales son, la sinonimia que existe en el Código Civil entre nulidad relativa y rescisión (i) y la historia fidedigna del establecimiento de los artículos 1857 y 1860 contenidos en dicho cuerpo normativo ${ }^{46}$ (ii), que, como tendremos ocasión de constatar, al igual que aquel, resultan controvertibles.

\section{i. La expresión "rescisión" contenida en los artículos 1857 y 1860 equivale a nulidad relativa}

Un primer argumento para postular la naturaleza anulatoria de la acción redhibitoria consiste en asimilar la expresión "rescisión" a "nulidad relativa", a partir de un examen de las normas contenidas en el Código Civil, especialmente en el Título XX del Libro IV titulado "De la nulidad y la rescisión", entendiéndose que, con la primera expresión, el legislador se ha querido referir a la nulidad absoluta y ha empleado la segunda para aludir a la nulidad relativa. Particular relevancia adquiere el inciso final del artículo 1682, pues después de indicar las causales de la nulidad absoluta, prescribe que "cualquiera otra especie de vicio produce nulidad relativa, y da derecho a la rescisión del acto o contrato" ${ }^{47}$, vinculándolas indisolublemente en una relación cuyo alcance es necesario precisar.

$\mathrm{Y}$ es que una revisión de la doctrina nacional y comparada revela que esta sinonimia no ha sido unánimemente aceptada. En efecto, por una parte, se ha sostenido que su equiparación es un mito jurídico, pues entre ellas existe una relación de causa a efecto, en términos tales que la rescisión es el efecto y su causa la nulidad relativa ${ }^{48}$. De otro lado, se ha apuntado que ellas no pueden equipararse, pues constituyen formas de ineficacia, distintas e independientes, toda vez que su fundamento, naturaleza y efectos son diversos ${ }^{49}$.

Claro está que, desde una perspectiva estrictamente jurídica, la voz "rescisión" se define como la "anulación o invalidación de algún contrato, obligación o testamento" ${ }^{50}$, de modo que, al menos en principio, podría asimilarse a la nulidad relativa. Este alcance amplio encontró en los textos romanos diferentes sentidos, motivo por el cual no puede atribuírsele un significado técnico y preciso, lo que impide delimitarla, incluso, de la restitutio in integrum. Con todo, las fuentes revelan que la nulidad era un concepto extraño al pensa-

\footnotetext{
45 Barros (1932) pp. 150-151, GUZMÁn (2007) pp. 100 y 110-111 y BARAONA (2008) pp. 661-662 y 665668.

46 GuZMÁn (2007) pp. 100 y 110-111 y BARAONA (2008) pp. 661-662 y 665-668.

47 Rodríguez (1995) pp. 288 y ss., Alessandri (2008) pp. 9 y ss., Baraona (2008) p. 660, nota 4, y AlCAlde (2010) pp. 68-69.

48 BaraOna (2008) pp. 666 y 667 y AlCALde (2010) pp. 47-77, quien sostiene que así lo evidenciaría su recepción en nuestro Código Civil

49 Martín (1995) pp. 190-192 y 208-210, Díez-Picazo (2007) p. 613, Alberruche (2010) pp. 158-159.

50 EsCriche (1998) p. 603.
} 
miento clásico y que los juristas de la época distinguieron el acto utile e inutile, vinculando esta última denominación a rescindere o rescissio para significar que, si un determinado acto es inútil o ha quedado inutilizado por el magistrado o por la ley respecto de algunos de sus efectos, queda plenamente válido para los demás ${ }^{51}$. Posteriormente, en el derecho francés intermedio, continuó la distinción entre nulidad y rescisión, a través de la contraposición entre nulidad absoluta o de pleno derecho -que permitía obtener lo que se había dado o entregado por el contrato celebrado- y aquella que para ser alegada por la action en rescission requería de una autorización previa que constaba en la lettre royaux o lettre de rescission. Tales categorías dogmáticas alcanzaron una clara delimitación en sus causas y efectos con la precisión que realizó DOMAT ${ }^{52}$ en torno a la diferencia entre "restitución" y "rescisión” y la enunciación que formuló POTHIER ${ }^{53}$ de las causas de rescisión ${ }^{54}$.

Esta distinción entre nulidad absoluta y relativa será seguida por Altimaro quien sistematizará tres supuestos de ineficacia: los contratos nulos ipso facto, actos anulables con efectos ex tunc y actos rescindibles con eficacia ex nunc $c^{55}$. Dicha tipología que, finalmente, se diluirá en el Code acarreará como consecuencia que se exija siempre la declaración judicial para que ella produzca efectos y que la nulidad relativa se conciba como sinónimo de rescisión. Este fenómeno no se advierte en el Código Civil español que la regula especialmente en el Capítulo V del Título II del Libro IV bajo el epígrafe "De la rescisión de los contratos", como una forma de ineficacia de menor intensidad que la nulidad, contemplándola en el artículo 1291 para cinco supuestos y concibiéndola expresamente en el artículo 1486 para los vicios redhibitorios ${ }^{56}$. Otro tanto se advierte en el Codice, pues destina a ella el Capítulo XIII del Título II del Libro IV, bajo la rúbrica Della Rescissione del contratto, introduciendo una causal novedosa en el artículo 1447, en comparación al Código Civil español, cual es, el contrato celebrado en estado de peligro $^{57}$.

51 Martín (1995) pp. 82-83, Alberruche (2010) pp. 29-31 y Alcalde (2010) pp. 50-51.

52 Indica que la rescisión procede por fuerza, error, engaño y venta de un inmueble en que el precio es menor a la mitad del justo precio (DOMAT (1841a) p. 279); en tanto, la restitución tiene lugar respecto de ciertas personas en razón de su calidad, como los menores (DомAт (1841b) pp. 168-169).

53 Los casos de rescisión a los que alude son la restitutio in integrum que opera respecto de los menores, la violencia, temor, dolo, error y lesión (POTHIER (1861) pp. 348-359.

54 Un análisis en De Castro (1985) pp. 517-518, Martín (1995) pp. 203-206, Coing (1996a) p. 534 y Coing (1996b) pp. 552-553, Cumyn (2002) pp. 21-46 y 119-126 y AlCAlde (2010) pp. 53-55.

55 Coing (1996a) p. 524-525 y AlCalde (2010) pp. 52-53.

56 Tales son: a) los contratos que celebraren los tutores sin autorización judicial, siempre que las personas que representan hayan sufrido lesión en más de la cuarta parte del valor de la cosa objeto de aquellos, b) los celebrados en representación de los ausentes en la medida que hayan sufrido tal lesión y c) en fraude a los acreedores cuando no pudieren cobrar lo que se les debe; d) los contratos que versen sobre cosas litigiosas cuando fueren celebrados por el demandado sin conocimiento y aprobación de las partes litigantes o del juez competente; e) cualquier otro caso en que la ley permita la rescisión. Por su parte, el artículo 1292 agrega los pagos hechos en estado de insolvencia por obligaciones a cuyo cumplimiento no podía ser compelido el deudor al tiempo de hacerlos. Sobre los motivos para regular separadamente la rescisión y nulidad véase De CASTRO (1985) pp. 518-528 y AlberRuche (2010) pp. 153-168.

57 Las otras causales de rescisión que contempla son la lesión enorme en los contratos conmutativos (artículo 1448) y en la partición de bienes (artículo 763). 
La detenida reglamentación de la rescisión en el Código Civil español explica que haya sido principalmente la doctrina española, liderada por Federico de Castro y Bravo ${ }^{58}$, la que destinara sus esfuerzos a delimitarla de la nulidad relativa, definiéndola como aquella forma de ineficacia que, a diferencia de la anulabilidad, no deriva de un vicio del negocio ni viene a declarar la existencia de este, sino que se limita a evitar al protegido un perjuicio que se estima especialmente injusto. En otras palabras, ella procede respecto de un acto válidamente celebrado, pero que, produciendo un perjuicio a una de las partes o a un tercero, puede ser declarado ineficaz a petición del perjudicado.

De allí que se señalen como diferencias que la nulidad encuentra su fundamento en algún vicio o defecto de los elementos esenciales del acto, en cambio la rescisión en un agravio jurídico-económico, destacándose el carácter principal de la primera y subsidiario de la segunda y precisándose que la nulidad tiene un efecto invalidatorio y la rescisión sería compatible con la subsistencia total o parcial del vínculo contractual o, en ocasiones, se traduciría en una compensación de la lesión inferida. Asimismo, se ha indicado que la nulidad es un tipo de ineficacia estructural que exige se pruebe el vicio del que adolece el negocio, a diferencia de la rescisión, que constituye una forma de ineficacia funcional en que debe probarse el perjuicio que el contrato ocasiona ${ }^{59}$.

Pues bien, estimamos que tales disquisiciones resultan plenamente aplicables a nuestro Código Civil, aun cuando pudiera sostenerse que la supresión del artículo 1865 del Proyecto de 1853 sería un argumento contundente para postular que el legislador quiso hacer equivalentes nulidad y rescisión, toda vez que este efectivamente las diferenciaba ${ }^{60}$. En efecto, como acertadamente indica Alcalde, la eliminación de dicho precepto no implica una sinonimia entre nulidad y rescisión, sino una mayor dificultad para diferenciarlas, que puede superase a partir de una relectura de las normas que la regulan en el Código Civil, pues ella revela que la nulidad es una de las causas de la rescisión, pero no la única ${ }^{61}$. Por tal motivo, Baraona se distanció en su oportunidad de la noción de rescisión acuñada por la dogmática española y precisó que es el efecto propio de un acto viciado estructuralmente (ab initio) o que adolece de defectos funcionales que causan una lesión patrimonial a las partes contratantes, de modo que la nulidad relativa sería su causa, como lo confirmaría el inciso final del artículo 1682, al disponer que aquella "da derecho a la rescisión del acto o contrato" ${ }^{\prime 2}$. Miradas las cosas desde esa perspectiva, la acción redhibitoria tendría una naturaleza anulatoria, pero atendida la segunda parte de tal noción, que es concordante con la acuñada por De Castro y Bravo, también podría calificarse como rescisoria por lesión enorme o rescisoria stricto sensu en los casos que ella no tiene lugar.

\footnotetext{
58 De Castro (1985) p. 520, Martín (1995) pp. 190-193 y 221, Alcalde (2010) pp. 69 y 73 y Alberruche (2010) pp. 168-169.

59 Martín (1995) pp. 190-192 y 208-210, Díez-Picazo (2007) p. 613 y Alberruche (2010) pp. 158-159.

60 Un estudio de la historia de la rescisión en el Código Civil en Mosquera (1998).

${ }_{61}$ Alcalde (2010) pp. 68-73, quien indica que en nuestro Código Civil y el Código de Comercio la rescisión carece de un sentido técnico preciso, pues equivale a la anulación o invalidación, a diferencia del Código de Procedimiento Civil que la recoge unívocamente al designar dos casos de nulidad procesal.

62 Baraona (2008) pp. 666-667.
} 
Y es que, como tendremos ocasión de analizar más detenidamente, a nuestro juicio, existen argumentos suficientes para sostener que el legislador, al aludir a la rescisión en los artículos 1857 y 1860, entendió que la causa de aquella era la lesión enorme o el desequilibrio patrimonial propio de la rescisión y no la nulidad relativa. De hecho, y como lo hemos apuntado precedentemente, la nulidad relativa y rescisión constituyen formas de ineficacia que difieren en cuanto a su fundamento, características, formas de interposición y efectos, contraposición que se verían reflejada, entre otros, en los artículos 1348, 1351, 1353, 1567 $\mathrm{N}^{\circ} 8$ y 2460, a partir de la utilización de la conjunción disyuntiva "o", toda vez que ella puede designar una relación de equivalencia -que ya ha quedado descartada- o de alternancia exclusiva y excluyente, como ocurre en el caso que venimos comentando.

Por otra parte, como se ha podido constatar, resulta indiscutido que la rescisión no es privativa de la nulidad relativa en nuestro Código, sino que también admite como causal la lesión enorme o el desequilibrio prestacional en casos que esta última no tiene cabida. Por lo mismo, abogar por la naturaleza anulatoria de la acción redhibitoria y sostener que los defectos de la cosa que constituyen el presupuesto de aquella pueden subsumirse en la categoría de vicios del consentimiento, es discutible, porque ellos parecen avenirse mejor con la noción de rescisión, en aquella parte, según la cual, esta procede si la celebración de un contrato ha ocasionado una lesión patrimonial a uno de los contratantes. A ello se agrega que, como lo expondremos al tratar la tercera premisa sobre la que se ha sustentado la naturaleza anulatoria de la acción redhibitoria, el vicio redhibitorio no es coincidente con el vicio del consentimiento.

ii. El reemplazo de la expresión "resuelva" por "rescinda" en el artículo 1857 y "resolución" por "rescisión” en el artículo 1860 revela la intención del legislador de otorgarle a la acción redhibitoria un carácter rescisorio

El examen de la historia fidedigna del establecimiento de los artículos 1857 y 1860 realizado en el apartado precedente, permite constatar una predilección del legislador por la "rescisión" al momento de regular la acción redhibitoria, reemplazando cualquier alusión a la "resolución" en el Proyecto Inédito y en la versión definitiva del Código Civil, enmienda que no ha estado exenta de críticas, ya que la mayoría de nuestra doctrina estima que esta constituye un error técnico, pues en verdad don Andrés Bello quiso referirse a la resolución ${ }^{63}$.

Sin embargo, en la última década, se ha justificado la pertinencia de tal modificación en dos consideraciones dogmáticas: una relativa a la cercanía de la acción redhibitoria al régimen de la rescisión más que al de la resolución y, la otra, referente a la noción de rescisión. En lo que concierne a la primera, Guzmán ha indicado que si dicha acción fuera resolutoria procedería la indemnización del daño emergente y el lucro cesante derivados del vicio, en los términos del artículo 1489, en circunstancias que no era el diseño con que venía concebida, pues esta solo daba lugar a la restitución de la cosa y el precio, sin indemnización. Tal modelo, que concibe como independiente a la indemnización, precisa, es más cercano al de la rescisión que solo da lugar a las restituciones mutuas, dado que rescindido

63 Véase los autores indicados en las notas 21 y 22. 
el contrato se entiende que las partes no estuvieron obligadas a cumplirlo, de modo que no se les podría exigir responsabilidad alguna ${ }^{64}$.

Cierto es que la acción redhibitoria es distinta a la indemnización por vicios redhibitorios, como fluye de sus diversos fundamentos, naturaleza jurídica, finalidad y requisitos de procedencia y de la interpretación armónica de los artículos 1861, 1866, 1867 y 1869 del Código Civil que permite establecer que el plazo de prescripción de esta se rige por el artículo 2515 y no por aquellos ${ }^{65}$. Pero, un fenómeno similar se ha advertido tratándose de la indemnización por incumplimiento en relación a la resolución por inejecución, pues, como lo ha admitido un sector de la civilística nacional y sentencias recientes de la Corte Suprema, esta puede demandarse independientemente de ella ${ }^{66}$, lo que no obsta a que el acreedor la intente en forma complementaria ${ }^{67}$. De otro lado, la declaración de la rescisión podría acarrear daños que deben indemnizarse para dejar a las partes en el estado en que se encontraban antes de la celebración del contrato, de modo que concurriría junto a ella, más aún si el autor la equipara a la nulidad relativa, pues esta admite supuestos de indemnización complementaria ${ }^{68}$.

En lo que respecta a la noción de rescisión como consideración para calificar a la acción redhibitoria de anulatoria, Baraona señala que el redactor del Código Civil comprendía perfectamente la diferencia entre rescisión y resolución y ese fue precisamente el motivo por el que modificó el artículo 360 del Proyecto de 1846-1847 y el artículo 2041 en el Proyecto Inédito, pues no solo la concebía como una desvinculación derivada de la lesión patrimonial que la celebración de un contrato ocasiona a una de las partes, sino también como consecuencia de un vicio de nulidad relativa. Dicha nulidad encontraría entonces, al menos en este supuesto, un fundamento diverso de la protección del interés particular de los contratantes, lo que se desprendería de la expresión "cualquier otra especie de vicio produce nulidad relativa y da derecho a la rescisión del contrato", contenida en la parte final del artículo 1682, cuya amplitud permitiría subsumir la figura de los vicios redhibitorios y sostener que la rescisión es el efecto de la nulidad ${ }^{69}$.

Otra razón, que a la fecha no se ha indicado, pero que podría explicar las enmiendas que venimos comentando, es una de las premisas que destacamos en el apartado precedente para descartar la naturaleza resolutoria de la acción redhibitoria. Y es que, según fluye de los artículos 1824 y 1837 del Código Civil, y salvo que las partes pacten que la obligación

\footnotetext{
64 GuZMÁn (2007) p. 100. Una explicación similar en Morales (2012) p. 17.

65 Guzmán (2007) pp. 115-117 y 119, De la Maza (2010) p. 457, nota 10, Oviedo (2014a) pp. 262-266, López (2016), pp. 666-674. En la jurisprudencia destacan las sentencias pronunciadas por la Corte Suprema en LARZABAL BERAZA CON SOCIEDAD INMOBILIARIA TALASIA LTDA. (2008) considerando $10^{\circ}$ y $11^{\circ}$, IMPRESION J.A. AMENABAR LTDA. CON IVÁN FUENTES RIQUELME (2008) considerandos $3^{\circ}$ y $4^{\circ}$, EMPRESA CONSTRUCTORA DE VIVIENDAS ECONÓmicas con Supermercado de Materiales de la Construcción Ltda. (2010) considerando $4^{\circ}$, AGF Allianz Compañta de Seguros Generales S.A. con Le Torneau Inc. (2010) considerando $12^{\circ}$ y $13^{\circ}$, Bogaris Agriculture Chile S.A. con Vial Budgee (2015) considerando $5^{\circ}$ y Montes con Automotora ComerCial COSTABAL Y ECHEÑIQUE S.A. (2015) considerandos $5^{\circ}$ y $6^{\circ}$.

66 Véase LÓPEZ (2014b) pp. 139-207.

67 Consúltese principalmente CONTARDO (2015).

68 Para tales supuestos Rodríguez (1995) pp. 296-303 y Baraona (2012) pp. 83-101.

69 Baraona (2008) pp. 666-667.
} 
de entrega comprende una cosa exenta de vicios redhibitorios, el legislador concibió a las acciones edilicias como acciones de garantía que pertenecen, por lo mismo, al régimen de saneamiento propio del contrato de compraventa y no a los medios de tutela por incumplimiento. Miradas las cosas desde esa perspectiva, resulta lógico que se le atribuya a la acción redhibitoria una naturaleza rescisoria, toda vez que la gravedad de los vicios que afectan a la cosa debe permitir al comprador desvincularse del contrato a través de alguna forma de ineficacia.

Sea como fuere, existe una voluntad específica del legislador en orden a establecer que la acción redhibitoria es de naturaleza rescisoria, pero como lo abordaremos en el próximo apartado cuando examinemos si es posible concebirla como una acción rescisoria por lesión enorme o rescisoria stricto sensu en los casos que ella no tiene lugar, el origen y el alcance de la expresión "rescisión" no la constriñe necesariamente a la nulidad relativa, toda vez que, como lo demostraremos a continuación, la premisa según la cual existe coincidencia entre el error sustancial y el vicio redhibitorio resulta controvertible.

\section{iii. El error sustancial es coincidente con el vicio redhibitorio.}

Una tercera premisa que se ha invocado para justificar la naturaleza anulatoria de la acción redhibitoria es que, en aquellos casos que la cosa adolezca de un vicio grave, injusto y determinante, existiría también un supuesto de error sustancial que facultaría al contratante, cuyo consentimiento está viciado, a demandar la nulidad relativa del acto, toda vez que, según el inciso primero del artículo 1454 del Código Civil, este se configura si la sustancia o calidad esencial del objeto sobre el que versa el acto o contrato es diversa de lo que se cree.

Atendido que existe consenso en la doctrina nacional reciente que puede abogarse por una noción funcional de vicios redhibitorios en nuestro Código Civil ${ }^{70}$ y que estos son defectos físicos, ocultos e inherentes a la cosa que se relaciona con su calidad y no con una prohibición legal ${ }^{71}$, la coincidencia entre ambos debería, en principio, fluir lógicamente, al menos en lo que concierne a la cualidad esencial, pues podría ocurrir que la inexistencia de aquella se traduzca precisamente en un vicio oculto, grave y preexistente. Este fenómeno no resulta tan claro si el error recae en la sustancia de la cosa, pues podría discutirse si, en tal caso, se configura un vicio redhibitorio (porque esta es defectuosa) o una hipótesis de incumplimiento por entrega de una cosa diversa a la pactada (aliud pro alio) que le permitiría optar entre la resolución y la acción redhibitoria ${ }^{72}$.

De hecho, la doctrina comparada, desde antiguo, ha formulado variados criterios de distinción entre los vicios redhibitorios y el error sustancial que no resultan totalmente satisfactorios, pues no los deslindan suficientemente. Así, la dogmática italiana y francesa sostuvo que las cualidades sustanciales determinaban la existencia de error y las no sustan-

\footnotetext{
70 Barrientos (2011) pp. 373-374 y Oviedo (2010) p. 262.

71 Alessandri (2003), Vol. I. p. 213, Oviedo (2010) p. 262, Barrientos (2011) pp. 373-374 y De La Maza (2012b) pp. 646-650.

72 Sobre esta distinción en la doctrina y jurisprudencia nacional véase LÓPEZ (2014a) pp. 605-624, DE LA MAZA (2014) pp. 123-125, 128-132 y 136-138 y BARRIENTOS (2015) pp. 135-154.
} 
ciales quedaban relegadas a los vicios redhibitorios, la alemana postuló que el vicio supone un desajuste entre las cualidades declaradas y reales y el error entre la cualidad querida y aquella declarada existente y, alguna doctrina española, incluso sugirió que tales vicios constituían un supuesto de imposibilidad parcial de la prestación ${ }^{73}$.

En la doctrina nacional, Baraona, recogiendo la premisa según la cual el vicio redhibitorio coincidiría con el error sustancial, ha sostenido que la gravedad que exige el artículo $1858 \mathrm{~N}^{\circ} 2$ debe entenderse como la proyección de un elemento subjetivo que se apoya sobre el error del comprador, pues, al momento de contratar, desconoce el desperfecto de la cosa, agregando que la amplitud de la expresión "cualquier otra especie de vicio", contenida en el inciso final del artículo 1682, puede comprender los "vicios redhibitorios". Por lo mismo, postula que existiría una doble lesión que se manifiesta en un desequilibrio objetivo (la cosa no sirve para su uso natural o convenido o sirve imperfectamente) y en el consentimiento contractual ${ }^{74}$.

Lo cierto es que, a pesar de la amplitud de tal expresión, la acción de nulidad y la redhibitoria, tienen un supuesto de hecho y una finalidad diversa y la diligencia que se exige al comprador en uno y otro caso es distinta. En efecto, para que resulte procedente la nulidad por error sustancial se requiere que se entregue una cosa diversa a la que se creyó comprar o que carezca de una cualidad que se tuvo presente para adquirirla, pero que no adolezca de vicios que la hagan inadecuada para su fin. En cambio, el ejercicio de la redhibitoria supone que la sustancia de la cosa es la misma que se creyó, pero resulta inútil en razón de los vicios de los que adolece, sin que se exija el error del comprador, toda vez que es de ejercicio objetivo ${ }^{75}$. Y es que, como señala Morales, en este último caso no basta el error, sino que importa el efecto derivado de aquel (inutilidad de la cosa o precio excesivo), lo que explica que las consecuencias del saneamiento por vicios sean más complejas, pues intentan corregir el daño sufrido por el comprador en razón del defecto de la cosa ${ }^{76}$.

Por otra parte, la acción de nulidad tiene por propósito tutelar el consentimiento de los contratantes, protegiendo su interés de no vincularse si existe una voluntad viciada, prescindiendo del perjuicio del errans para impetrarla. Las acciones edilicias, por el contrario, persiguen proteger al comprador del perjuicio que experimenta como consecuencia del defecto que inutiliza la cosa o la hace menos valiosa, configurándose la lesión patrimonial o el perjuicio del comprador como supuesto de procedencia. Además, el grado de diligencia que se exige al comprador para que pueda invocar error sustancial o un vicio redhibitorio es diverso. En el primer supuesto, como el error debe ser excusable, se requiere que emplee una diligencia media para comprobar que la cosa tiene las cualidades que presupone; en

\footnotetext{
73 Un detallado resumen en Bercovitz (1969) pp. 780-796 y Morales (1980) pp. 671-675, postulando el primero de estos autores que los vicios redhibitorios constituyen un supuesto de imposibilidad parcial de la prestación (Ibíd. pp. 801-809).

74 BaraOna (2008) pp. 660, 667 y 668.

75 Barros Errázurriz (1932) pp. 150, 151-152 y Alessandri (2003), Vol. I p. 188. En la doctrina comparada Célice (1920) p. 212, Bercovitz (1969) p. 804 y Morales (1980) pp. 676 y 677.

76 Morales (1980) p. 676.
} 
cambio, en el segundo, debe haber empleado una mínima diligencia para cerciorarse que la cosa que compra está exenta de vicios ${ }^{77}$.

A tales diferencias se agregan tres efectos propios de los vicios redhibitorios, pero que no tienen cabida en la nulidad por error. En primer lugar, el legislador permite al comprador modificar la relación contractual en el evento que los defectos no revistan el carácter grave que exige el numeral 2 del artículo 1858, a través del ejercicio de la acción quanti minoris, alternativa que no se admite tratándose del error. En segundo lugar, el artículo 1859 del Código Civil permite pactar que el vendedor no esté obligado al saneamiento de los vicios redhibitorios - salvo que haya tenido conocimiento de ellos y no haya dado noticia al comprador-, facultad que no se advierte en la nulidad, toda vez que, como se desprende del artículo 1469, no puede renunciarse anticipadamente, porque protege los intereses superiores de la colectividad ${ }^{78}$. En tercer lugar, en los vicios redhibitorios es el comprador el que puede intentar la acción redhibitoria en contra del vendedor, lo que no ocurre tratándose del error, toda vez que este puede ejercer la acción de nulidad en contra del comprador si ha enajenado algo de calidad muy superior a la que él creía ${ }^{79}$.

En atención a todas las consideraciones que hemos apuntado, puede sostenerse que el error sustancial no necesariamente coincidirá con un vicio redhibitorio. En principio, nada obstaría a que la sustancia o cualidad esencial de la cosa sobre la que recae el error constituya a la vez un desperfecto funcional ${ }^{80}$, pues la gravedad del vicio que exige el artículo $1858 \mathrm{~N}^{\circ} 2$ es de cierto modo coincidente con la entidad que el artículo 1454 requiere para que el error sea sustancial. Sin embargo, el grado de diligencia exigible para el error vicio y el vicio redhibitorio impide efectuar tal equiparación. Por otra parte, es efectivo que la lesión económica que experimenta el comprador como consecuencia del vicio oculto es el dato prioritario al que atienden las acciones edilicias, pero tal constatación, a nuestro juicio, no permite sostener que el sustrato de la acción redhibitoria sea una lesión en el consentimiento contractual que causa daño ${ }^{81}$, sino más bien afirmar que se trataría de una rescisión por lesión enorme o una rescisión stricto sensu en los casos que ella no tiene lugar, toda vez que, como profundizaremos más adelante, dicho vicio o desperfecto produce un desequilibrio que causa un perjuicio económico al comprador.

Finalmente, cabe destacar que el legislador, al prescribir en el artículo 1824 del Código Civil que una de las obligaciones del vendedor es el saneamiento de la cosa vendida y precisar, en el artículo 1837, que esta puede implicar responder de los vicios redhibitorios, concibe al saneamiento de tales vicios como una obligación que emana del contrato de compraventa válidamente formado, argumento que no solo nos lleva a reiterar nuestro rechazo a la tesis que aboga por la naturaleza resolutoria de la acción redhibitoria, sino a

\footnotetext{
77 De Verda (2009) pp. 243-248.

78 Una idea similar en Bercovitz (1969) p. 789 y De Verda (2009) p. 252. En efecto, el artículo 1469 prescribe que "los actos o contratos que la ley declara inválidos, no dejarán de serlo por las cláusulas que en ellos se introduzcan y en que se renuncie a la acción de nulidad".

79 Célice (1920) p. 212, Bercovitz (1969) p. 788, De Verda (2009) pp. 239-240, Morales (1980) pp. 677678.

80 Baraona (2008) p. 661.

81 Baraona (2008) p. 662, notas 9 y 668.
} 
descartar su carácter anulatorio, toda vez que estamos ante un contrato que no adolece de vicios estructurales, sino ante un contrato válido.

\section{c) LA NATURALEZA RESCISORIA DE LA ACCIÓN REDHIBITORIA: LA TESIS INEXPLORADA}

De lo dicho hasta acá ha quedado establecido que la acción redhibitoria no es resolutoria ni anulatoria, toda vez que se trata de una acción de garantía y no de incumplimiento contractual y que el vicio redhibitorio no es absolutamente coincidente con el error sustancial, lo que en ningún caso impide, al menos doctrinariamente ${ }^{82}$, el ejercicio de tales acciones en vez de la redhibitoria si concurren sus presupuestos. La pregunta que surge, entonces, es qué naturaleza jurídica pretendió atribuirle el legislador a esta acción cuando empleó la voz "rescisión" en los artículos 1857 y 1860 del Código Civil.

Atendido el estado actual de la cuestión en la civilística chilena, podría pensarse que esta interrogante no tendría una respuesta diversa a la que han propuesto las dos teorías que hemos venido examinando, toda vez que los autores se han dividido entre una u otra y no han formulado una propuesta diversa que supere las críticas que ellas admiten para alcanzar una solución definitiva que otorgue certeza al comprador respecto del interés que resulta tutelado con la interposición de esta acción y los efectos que de ella se derivan. Sin embargo, arribar a esta conclusión equivaldría a admitir que existen dos soluciones erradas para un problema jurídico y que, cualquiera sea la que apliquemos, lo estaremos resolviendo incorrectamente, lo que resulta jurídicamente inadmisible.

De allí que sea necesario indagar si existe una tercera alternativa a la que podamos recurrir, que no admita las falencias detectadas con ocasión de la doctrina que la califica como resolutoria y aquella que aboga por su carácter anulatorio y resulte más adecuada, no solo desde la historia fidedigna del establecimiento de los artículos 1857 y 1860, sino desde una perspectiva práctica y dogmática. Estimamos que para alcanzar tal propósito debemos recurrir, primeramente, a la rescisión por lesión enorme y, en su defecto, a la rescisión stricto sensu, y sostener, por consiguiente, que esta sería la naturaleza jurídica de la acción redhibitoria.

La idea de concebirla como rescisoria por lesión enorme, si bien fue sugerida en España por José de Verda y Beamonte en el año 2004 y retomada el 2012 por Antonio Manuel Morales Moreno ${ }^{83}$, hasta ahora no ha sido explorada en la civilística nacional, probablemente porque, desde antiguo, se ha concebido a la lesión enorme como una institución de aplicación excepcional y restringida a los supuestos previstos por el legislador, a lo que se añade que no se ha indagado mayormente la noción de rescisión y su delimitación respecto de la nulidad relativa ni la admisibilidad de esta particular forma de ineficacia en nuestro Código Civil ${ }^{84}$.

Con todo, tales autores no han esgrimido argumentos que permitan sostener indubitada y decididamente su procedencia, pues se han inclinado, indistintamente por la rescisión por lesión enorme y por la nulidad relativa o exclusivamente por la primera,

\footnotetext{
82 Véase notas 29 y 36.

83 De Verda (2004) pp. 244-249, idea que mantiene en De Verda (2009) pp. 299-301 y Morales (2012) p. 17.

84 Excepcionalmente han abordado este tópico BaraOna (2008) pp. 666-668 y AlCalde (2010) pp. 48-78.
} 
con la finalidad de contraponerlas a la resolución y excluirla de su naturaleza resolutoria. Así, Morales precisa que la función de la acción redhibitoria se aproxima a la anulación del contrato por error o a la rescisión por lesión enorme, toda vez que ofrecen al contratante la posibilidad de desvincularse sin los medios de tutela orientados a la satisfacción del interés positivo ${ }^{85}$. Como se advierte, justifica su planteamiento por exclusión, mas no aborda la naturaleza jurídica de la acción redhibitoria a partir de la finalidad, fundamento y particularidades de la rescisión por lesión enorme. En tanto, De Verda se aproxima más a este análisis, dado que sostiene que ambas acciones persiguen el restablecimiento del desequilibrio prestacional y que, a partir del tenor el artículo $1291 \mathrm{~N}^{\circ} 5$ del Código Civil español, que dispone la procedencia de la rescisión por lesión "en cualquiera otro caso en que especialmente lo determine la ley", es posible subsumir la existencia de vicios ocultos en ella ${ }^{86}$.

Por lo mismo, sustentar esta teoría entre nosotros requiere un esfuerzo dogmático más detenido que, en parte, hemos adelantado al distinguir la rescisión de la nulidad relativa y precisar el alcance normativo de la primera en el Código, pero que ahora debemos profundizar, vinculando la rescisión por lesión enorme a la acción redhibitoria con el propósito de intentar equipararlas, a partir de determinadas premisas dogmáticas que resulten aplicables al derecho civil chileno. Los argumentos que nos permitirán alcanzar este objetivo son los siguientes: i) La rescisión por lesión enorme es una forma de ineficacia civil que, al igual que la acción redhibitoria, persigue el restablecimiento del equilibrio contractual originario; ii) La acción rescisoria por lesión enorme es de ejercicio objetivo; iii) Procede respecto de casos de desequilibrio prestacional grave, expresamente regulados por el legislador y iv) No se admite en las ventas realizadas por el ministerio de la justicia.

Estos argumentos demostrarán que, aun cuando no hubiéramos descartado la tesis que sustenta la naturaleza resolutoria o anulatoria de la acción redhibitoria, existe una mayor coincidencia entre esta última y la rescisoria por lesión enorme y que resulta irrelevante que nuestro Código contemple una norma similar al numeral 5 del artículo 1291 del Código español que establece su procedencia en "cualquiera otros en que especialmente lo determine la ley". Y es que, como el legislador utilizó expresamente la voz "rescisión" en los artículos 1857 y 1860, se trata de un supuesto indiscutido en que ella tiene lugar, sin que sea necesario que la vincule normativamente a la lesión enorme, pues atendido el perjuicio patrimonial que esta causa al comprador, no podría ser otra la causal que determine su procedencia.

\section{i. La rescisión por lesión enorme es una forma de ineficacia civil que, al igual que la acción redhibitoria, persigue el restablecimiento del equilibrio contractual originario}

Como hemos venido reiterando a lo largo de esta investigación, el propósito de la acción redhibitoria es tutelar la simetría que debe existir entre las prestaciones recíprocas, toda vez que su procedencia se justifica por el provecho que obtiene el acreedor del defecto

\footnotetext{
85 Morales (2012) p. 17.

86 De Verda (2009) pp. 299-301. Así también lo han estimado Llácer (1992) pp. 121-122 y Alberruche (2010) p. 265.
} 
de la cosa, pues conlleva una desproporción prestacional que debe corregirse. En otras palabras, dicha acción pretende proteger al comprador del perjuicio que experimenta como consecuencia del defecto que inutiliza la cosa o la hace menos valiosa, configurándose así tal lesión patrimonial y, consecuentemente, el enriquecimiento del vendedor derivado del vicio redhibitorio, como supuesto de procedencia ${ }^{87}$. Dicho propósito se alcanza situando al comprador en la posición en que se encontraría de no haber celebrado el contrato.

Pues bien, la rescisión por lesión enorme persigue la misma finalidad, pues, al igual que la acción redhibitoria, constituye una manifestación de equilibrio contractual inicial, originario o congénito, esto es, aquel que debe existir al momento de formación del consentimiento y que puede destruirse en aquellos supuestos en que una parte acepta las condiciones inicuas que la otra le impone ${ }^{88}$. En efecto, como es ampliamente sabido, la lesión enorme es aquel perjuicio patrimonial, que sufre una de las partes, derivado de la falta de equivalencia o desproporción de las prestaciones recíprocas, existente al momento de celebrar un contrato que, mayoritariamente se ha estimado, debe ser bilateral, oneroso y conmutativo, o tratándose un acto unilateral en los casos expresamente previstos por la ley, como acontece en el artículo 1234 del Código Civil a propósito de la aceptación de una aceptación hereditaria ${ }^{89}$.

De otro lado, un examen de nuestro Código permite constatar que ella lleva aparejada, en determinados supuestos, la rescisión, cuyo efecto, al igual que la acción redhibitoria, es restituir a las partes del contrato a un estadio anterior a la celebración del contrato, como si este nunca hubiera tenido lugar, tutelando así el interés contractual negativo. Con todo, podría pensarse que, atendido que ambas acciones protegen el mismo interés y revisten un carácter precontractual, no habría mayor diferencia con la acción de nulidad, pues se trataría de una tutela que revestiría características similares.

Sin embargo, el único supuesto que haría procedente la nulidad tratándose de vicios redhibitorios, es el error sustancial, pero, como hemos constatado en líneas precedentes, este no es coincidente con aquel, toda vez los supuestos de procedencia, grado de diligencia exigible y el propósito que persiguen las acciones derivadas de ellos son diversos, a lo que se agrega que el legislador no permite al comprador modificar la relación contractual en el supuesto de error ni pactar una cláusula en que se renuncie a la acción de nulidad.

$\mathrm{Y}$ es que el vicio redhibitorio solo evidencia que el comprador ha sufrido un perjuicio económico como consecuencia de la ruptura del equilibrio contractual originario, circunstancia que justifica la rescisión por lesión enorme, ya que ella, al igual que la redhibitoria, persigue evitar un resultado injusto, que se materializaría si el comprador que recibe la cosa defectuosa no pudiere accionar contra el vendedor, a pesar de que cumplió su obligación de pagar el precio en tiempo y forma ${ }^{90}$.

\footnotetext{
87 Morales (1980) p. 682, Llácer (1992) pp. 121-123, De Verda (2009) p. 299 y Alberruche (2010).

88 López (2015b) pp. 133-139.

89 Para una noción amplia de lesión enorme, extensiva a cualquier desequilibrio patrimonial véase LÓPEZ (2015a) pp. 699-723.

90 De Verda (2009) p. 301
} 


\section{ii. La acción rescisoria por lesión enorme es de ejercicio objetivo}

Un segundo argumento para atribuirle a la acción redhibitoria el carácter de rescisoria por lesión enorme es la similitud que esta última presenta con aquella en lo que concierne a la ausencia de imputabilidad del otro contratante para ejercerla. Y es que, como lo ha destacado la doctrina nacional, una revisión de los supuestos de lesión enorme que regula nuestro Código permite evidenciar que, a diferencia de los Códigos Civiles más modernos, el nuestro recoge un criterio objetivo o materialista, pues, de conformidad al tenor del artículo 1451 del Código Civil esta no constituye un vicio del consentimiento y se configura como consecuencia de una desproporción prestacional, prescindiendo de la intención del otro contratante de aprovecharse de la ligereza, inexperiencia o necesidad de dinero del otro para obtener una ventaja excesiva ${ }^{91}$.

Excepcionalmente se ha sostenido que es un vicio del consentimiento, reconduciéndolo al error sustancial, específicamente en las cualidades esenciales de la cosa, a partir de una interpretación armónica de los artículos 1454 y 1460 de nuestro Código, relativos al error sustancial y al objeto del contrato, respectivamente, denominándolo error en la magnitud de las prestaciones ${ }^{92}$, planteamiento que no solo se contrapone al referido artículo 1451 sino también a la historia fidedigna de su establecimiento ${ }^{93}$. Cuestión distinta es que sea más recomendable el criterio objetivo-subjetivo de lesión y que alguna doctrina nacional haya abogado por una modificación del Código en esta materia ${ }^{94}$.

Por su parte, una revisión histórica de las acciones edilicias ${ }^{95}$, evidencia que, desde antiguo, estas se concibieron como acciones de ejercicio objetivo, dado que, ya en el sistema romano, se prescindía de la culpa o dolo para hacer efectiva la responsabilidad del vendedor por los vicios redhibitorios, tendencia que también se advierte en los artículos 1857 y 1860 de nuestro Código, toda vez que ellas no exigen dolo o culpa, sino la sola existencia

91 Un panorama general de los criterios objetivo y objetivo-subjetivo de lesión enorme en Peñailillo (2000) pp. 216-219, Devoto (2004) pp. 153-169, Domínguez (2005) pp. 14-22 y, más recientemente, López (2017) pp. 659-664.

92 Ducci (1995) p. 267. Así, precisa el autor que el error en la calidad esencial del objeto, cuando este es una prestación, no puede ser otra cosa que su magnitud, de modo que si esta es distinta de lo que se ha creído, en términos tales que las prestaciones no puedan mirarse como equivalentes, el contrato adolece de error sustancial (Ducci [1995] pp. 267-269).

93 De hecho, el artículo 1638 del Proyecto de 1853, que aparentemente la concebía como vicio del consentimiento, fue suprimido. Con todo, como acertadamente lo ha destacado la doctrina más especializada, ni aun en dicho Proyecto lo fue, pues procedía cuando se verificaba el desequilibrio exigido por el legislador, sin que el precepto contemplara causas subjetivas que viciaran la voluntad de la víctima (Merello (1979) pp. 104 y 105 y GuZMÁn (1999) p. 8). En efecto, dicho precepto señalaba: "La lesión como causa de vicio en los contratos, es propia de los conmutativos; i para viciar un contrato, ha de ser enorme, esto es, tal que el valor de lo que el uno de los contratantes da al otro no llegue a la mitad del valor de lo que el otro reciba de él, no constando haber habido intención de donar el exceso. I no se entenderá haber habido tal intención sino cuando se mencionen específicamente las cosas o cantidades que se donan” (BELlo (1888), p. 388). Probablemente, advirtiendo este alcance objetivo, Bello decidió no calificarla como un vicio del consentimiento en la versión definitiva del Código Civil.

94 Peñailillo (2000) p. 220 y Domínguez (2012) p. 110.

95 Véase Morales (1980) pp. 596-599, Ferrante (2012) pp. 30-33, GuZmán (2013) pp. 166 y 168 y Oviedo (2014) pp. 201-240. 
de tales vicios ${ }^{96}$. Constituyen, por tanto, una forma especial de responsabilidad objetiva que encuentra su justificación en el hecho de que, aunque el deudor hubiera actuado de buena fe, obtiene provecho del vicio redhibitorio de la cosa, pues este igualmente le permitirá venderla u obtener un menor precio por ella ${ }^{97}$. Tal régimen de responsabilidad garantiza un mínimo de protección al acreedor frente a los defectos ocultos de la cosa que le resulta muy conveniente, tanto en aquellos casos en que no disponga de otro medio de tutela, como en los supuestos en que pueda recurrir a ellos, pues no tendrá que acreditar la mala fe del deudor, sino la sola existencia del vicio. De allí que pueda sostenerse que el ejercicio de la redhibitoria supone que la sustancia de la cosa sea la misma que se creyó, pero resulte inútil en razón de los vicios de los que adolece, sin que se exija el error del comprador ${ }^{98}$.

\section{iii. $\quad$ Procede respecto de casos de desequilibrio prestacional grave, expresamente regulados por el legislador}

Otra premisa sobre la cual se puede erigir la tesis que venimos sustentando es que, la acción rescisoria por lesión enorme, al igual que la redhibitoria, resulta aplicable a supuestos de desequilibro patrimonial grave, representados, en el primer caso, por una asimetría que supere el cincuenta por ciento del valor de la prestación, y, en el segundo, por un defecto que, según la noción de vicio redhibitorio que se adopte, disminuya su utilidad o impida destinarla a su uso natural (noción material) o a aquel para el cual fue adquirida (noción funcional), de manera que sea de presumir que, conociéndolo el comprador, no lo hubiere comprado o la hubiera comprado a mucho menor precio.

Y es que precisamente el legislador, a través del adjetivo calificativo enorme, pretende graficar la gravedad del desequilibrio que debe existir en la lesión para que proceda la rescisión tratándose de la compraventa y permuta de bienes inmuebles. En el primero de estos contratos, de conformidad al artículo 1889, esta se configura cuando el precio que recibe el vendedor es inferior a la mitad del justo precio de la cosa que vende y en los casos que el precio que paga el comprador excede al doble del justo precio de la cosa que compra. En el segundo, según el artículo 1900, resulta aplicable este mismo parámetro, considerándose a cada permutante como vendedor de la cosa que da y el justo precio de ella a la fecha del contrato se mira como el precio que paga por lo que recibe a cambio.

Si bien es cierto que se ha discutido que la partición de bienes y aceptación de una asignación hereditaria, efectivamente constituyen supuestos de lesión enorme ${ }^{99}$ en la medi-

96 Entre otros, Morales (1980) pp. 665 y 681-682, De Verda (2009) pp. 209-210 y 305, GuZmán (2007) pp. 98-99 y De la Maza (2010) pp. 456-458 y 461.

97 Morales (1980) p. 682.

98 Barros Errazurriz (1932) pp. 150, 151-152 y Alessandri (2003), Vol. I, p. 188. En la doctrina comparada Célice (1920) p. 212, Bercovitz (1969) p. 804 y Morales (1980) pp. 676 y 677.

99 Se ha sostenido que, en estricto rigor, no existiría una falta de equivalencia de prestaciones en tales casos. En la partición de bienes se ha indicado que el legislador permite solicitar su rescisión, ya que se infringe el principio de igualdad de los herederos que informa la partición de los bienes hereditarios (PeÑAILILLO (2000) p. 216). En tanto, en lo que concierne a la aceptación de una asignación hereditaria se ha fundado su procedencia en la equidad, pues existiría una menor ventaja patrimonial (Domínguez (2012) p. 106) o un perjuicio derivado de la ignorancia o error que no es imputable a quien acepta dicha asignación (PeñAILILLO (2000) p. 216). 
da que se admitan como tales, también se aprecia la desproporción excesiva según la métrica que venimos comentando, toda vez que, según el artículo 1348, tiene lugar en el primer supuesto cuando se ha perjudicado a un comunero en más de la mitad de su cuota, en tanto, de conformidad al artículo 1234, procede en el segundo, si existiendo disposiciones testamentarias de que no se tenía noticia al tiempo de aceptar la asignación hereditaria, esta disminuyere el valor total de la asignación en más de la mitad.

Otro tanto acontece en la acción redhibitoria, toda vez que la doctrina nacional ha entendido que la exigencia contenida en el artículo $1858 \mathrm{~N}^{\circ} 2$ del Código Civil equivale a la gravedad o relevancia de los vicios, discutiéndose, como ya lo hemos precisado, si estos existen cuando inutilizan total o parcialmente la cosa para el uso que motivó su adquisición (noción funcional) y no para su uso natural o pactado (noción material) ${ }^{100}$, asentándose en la jurisprudencia la primera postura ${ }^{101}$. De ahí que el vicio que desagrada al comprador, pero no afecta la utilidad de la cosa, como su coloración o tinte, los ruidos que esta pueda producir, la existencia de una servidumbre oculta o la obstaculización de la vista a un determinado paraje, no pueda calificarse de redhibitorios ${ }^{102}$.

Estos supuestos de desequilibrio desmesurado o desproporcionado en que procede la rescisión, se encuentran expresamente regulados y, atendido el carácter estricto de esta sanción de ineficacia ${ }^{103}$, y lo preceptuado en el artículo 1545 de nuestro Código que, en su parte pertinente, señala que los contratos no pueden invalidarse sino por consentimiento mutuo o causas legales, resulta inaplicable a otros casos no previstos por el legislador. Distinto es que, tanto, en la acción redhibitoria como en la rescisoria por lesión enorme, se faculte al comprador para inclinarse por conservar el contrato, instando por la rebaja de la prestación excesiva, circunstancia que viene a confirmar la cercanía y similitud que existe entre ambas ${ }^{104}$.

En efecto, en aquellos casos en que no se configure la gravedad que la ley exige para los vicios redhibitorios, el artículo 1868 niega al comprador la rescisión, pero lo faculta para inclinarse por la rebaja del precio, conservando el contrato. Un fenómeno similar, pero más excepcional aún -porque en este supuesto sí se configura la desproporción exigida por el legislador en el artículo 1889- se advierte en la lesión enorme, toda vez que, según lo dispone el artículo 1890 del Código Civil, el comprador contra quien se pronuncia la rescisión podrá, a su arbitrio, consentir en ella o completar el justo precio con deducción de una décima parte.

\footnotetext{
100 Sugiriendo este nuevo enfoque Barrientos (2011) pp. 373-374 y Oviedo (2010) p. 262.

101 Como lo revela el estudio jurisprudencial de Oviedo (2010) pp. 244-251.

102 Oviedo (2016) pp. 143-144.

103 De Castro (1985) pp. 520- 522, Martín (1995) pp. 229-230, Alcalde (2010) p. 74, Alberruche (2010) pp. 187-190.

104 Claro está que, tratándose de la nulidad por error sustancial, podría ensayarse, a partir de instrumentos de soft law, al igual como lo ha hecho la doctrina comparada (principalmente Morales (2011) pp. 412-414 y GASPAR (2014) pp. 301-304), la facultad de adaptar el contrato en los casos de error vicio unilateral y error compartido, alcanzando un resultado similar. Pero tal intento, al menos en este caso, resulta irrelevante, toda vez que ya hemos descartado la naturaleza anulatoria de la acción redhibitoria (Véase, Sección 1.B).
} 
Podría pensarse que, no obstante, este común denominador, la tutela que dispensa al comprador la rebaja del precio y la reducción de la prestación excesiva derivada de la lesión es diversa. Pero lo cierto es que eventualmente podrían coincidir, desde que no existe una fórmula definida en nuestro Código para calcular el monto de la primera, lo que dependerá del método de cálculo que sigamos -esto es, el método de resta o el proporcional puro ${ }^{105}$ - o del criterio que adoptemos - proporcionalidad, gravedad del vicio o los costos de reparación de la $\cos \mathrm{a}^{106}-\mathrm{y}$ del caso concreto que se presente.

\section{iv. No se admite en las ventas forzadas hechas por el ministerio de la justicia}

Una última coincidencia entre la acción rescisoria por lesión enorme y la redhibitoria, que deviene en un argumento adicional a nuestro planteamiento, es que ambas no proceden tratándose de las ventas realizadas por el ministerio de la justicia, según lo prescriben, los artículos 1891 y 1865 de nuestro Código Civil, prohibición que se remonta, en ambos casos, a la versión definitiva del Código Civil, como consecuencia de la influencia de los artículos 1649 y 1684 del Code, respectivamente ${ }^{107}$.

Según ha apuntado la dogmática nacional, la justificación de ambas prohibiciones es coincidente. En efecto, tratándose de la acción rescisoria por lesión enorme se ha indicado que la regla del artículo 1891 encuentra su explicación en el hecho que la publicidad propia de las ventas judiciales, por un lado, garantiza que el inmueble se venderá en el único precio en que podría venderse y, por otro, permite evitar fraudes ${ }^{108}$. En el caso del artículo 1865 la justificación es similar, pero no tiene lugar, si el vendedor no pudiendo o no debiendo ignorar los vicios de la cosa vendida, no los hubiere declarado a petición del comprador.

Claro está que, el argumento común para justificar la improcedencia de ambas acciones en las ventas forzadas realizadas por el ministerio de la justicia, es la especial modalidad de la venta. Miradas las cosas desde esta perspectiva, podría pensarse que el rasgo común no sería la naturaleza jurídica de ambas acciones, sino la circunstancia que la venta se realiza en pública subasta. Sin embargo, un análisis más detenido revela que la justificación de la proscripción de estas acciones radica en que ellas tienen un mismo fundamento, cual es, el restablecimiento del equilibrio contractual, toda vez que el legislador las descarta, precisamente, porque considera que, vendiéndose la cosa, cuyo valor determina una asimetría prestacional entre el comprador y el vendedor, con garantías de publicidad y libre concurrencia de postores, tal desequilibrio desaparece. Así acontecerá en un remate público en el

\footnotetext{
105 El método de resta identifica el precio de compra con el valor objetivo del bien, aun cuando pueden no coincidir, desestabilizando el equilibrio que se quiere restablecer, particularmente en los casos en que se entrega un aliud pro alio, se realiza una compra inferior al valor de mercado o se oferta un bien a un precio inferior al del mercado. En cambio, el método proporcional puro considera el precio estipulado del bien y la disminución de sus funcionalidades, debiendo cuantificarse el monto a disminuir necesariamente a través de un peritaje (Ferrante (2012) pp. 267-269).

106 Prado (2015) pp. 631-646.

107 En tanto, tratándose de ambos artículos ninguno de los preceptos que lo precedieron en los Proyectos de Código Civil contempló tal restricción en estos términos.

108 Alessandri (2003), Vol. I, p. 772 y Díez (2009) p. 435.
} 
juicio ejecutivo, en un remate en pública subasta en un juicio de liquidación y partición, o en las ventas en pública subasta en los actos de jurisdicción voluntaria que exigen tal trámite. Es, por consiguiente, un argumento más sustantivo que procedimental, el que justifica la restricción que venimos comentando.

El problema que puede suscitarse es que los vicios redhibitorios recaigan sobre cosas muebles, pues de conformidad al artículo 1891, la acción rescisoria por lesión enorme no procede, de modo que, en este caso, no podríamos atribuirle tal naturaleza a la acción redhibitoria, que según el artículo 1866 procede respecto de bienes muebles. Situados en este escenario tenemos tres alternativas posibles: a) entender que estamos ante una acción cuya naturaleza jurídica estaría determinada en caso de bienes inmuebles, pero no tratándose de muebles, lo que jurídicamente resulta inadmisible; b) sostener que ante este obstáculo insuperable debemos retornar a las teorías que postulan la naturaleza anulatoria o resolutoria de esta acción, opción que resulta ilógica, pues, como lo hemos demostrado en líneas anteriores, ellas no logran explicar la naturaleza jurídica de la acción redhibitoria y c) estimar que, en estos casos, si bien no procede la lesión enorme, la acción redhibitoria continúa siendo de carácter rescisorio, en sentido técnico estricto, toda vez que la venta de una cosa con vicios redhibitorios, si bien es válida, produce un perjuicio injusto que conlleva la ruptura del sinalagma contractual -supuesto propio de la rescisión- y cuya procedencia se encuentra prevista expresamente por el legislador -requisito insoslayable de esta forma de ineficacia-.

Ciertamente nuestro legislador no regula la acción rescisoria stricto sensu en un Título o apartado especial del Código Civil, pero alude a ella en disposiciones aisladas, a partir de las cuales puede concebirse a la rescisión como una forma de ineficacia extrínseca y funcional, cuya causa es originaria - pues deriva del desequilibrio prestacional que acarrea un perjuicio injusto- y que, por regla general, tiene un carácter subsidiario. Tal es el caso, como lo anticipamos, de los artículos 93 y 94 relativos al decreto de posesión efectiva del desaparecido, el artículo 1234 que regula la lesión enorme en la aceptación de una asignación hereditaria, los artículos 1348 y 1351-1353 ubicados en la partición de bienes, los artículos 1853-1854 y 1888-1898 a propósito de la compraventa, el artículo 1900 en lo que concierne a la permuta de inmuebles, el artículo 1384 relativo a las enajenaciones de bienes del difunto hechas por los herederos y el artículo $1567 \mathrm{~N}^{\circ} 8$ con ocasión de los modos de extinguir, si asumimos, como lo hemos hecho a lo largo de esta investigación, que la conjunción disyuntiva "o" contrapone tales formas de ineficacia y no las hace sinónimas.

Con todo, esta forma de ineficacia no es extraña a nuestra dogmática que, incluso, ha ensayado una teoría general de la rescisión en el Código Civil, caracterizándola como excepcional, constitutiva y subsidiaria, perfilando sus efectos ${ }^{109}$. Sin embargo, no la ha deslindado de la nulidad, sino que las fusiona ${ }^{110}$, lo que ciertamente constituye un correcto análisis desde la confusa e indistinta utilización que realiza el Código Civil de ellas, pero

109 En tal sentido AlCalde (2010) pp. 73-77.

110 Baraona (2008) pp. 666 y 667 y Alcalde (2010) pp. 73-74. 
que, tratándose de la naturaleza jurídica de la acción redhibitoria ${ }^{111}$, revela la necesidad de distinguirlas y delimitarlas, como lo hemos hecho en las líneas precedentes, pues tal noción amalgamada de rescisión no logra explicarla, toda vez que, por los argumentos que hemos esgrimido con antelación, no puede atribuírsele un carácter anulatorio.

\section{LA INCIDENCIA DE LA NATURALEZA JURÍDICA DE LA ACCIÓN REDHIBITORIA EN EL SISTEMA DE PROTECCIÓN DEL COMPRADOR}

Precisada nuestra postura en torno a la naturaleza jurídica de la acción redhibitoria, resulta necesario determinar cuáles son las consecuencias derivadas de adoptarla y la conveniencia que ella reporta al comprador en comparación a la resolución por incumplimiento y a la nulidad relativa por error sustancial. La respuesta a esta interrogante solo puede alcanzarse considerando el impacto que tal determinación tiene en el sistema de protección del comprador y contraponiendo los efectos derivados de tales formas de ineficacia a la rescisión por lesión enorme, pues ya ha quedado claro que se trata de figuras que descansan sobre fundamentos diversos, cuales son el consentimiento viciado, el incumplimiento y el desequilibrio contractual, respectivamente. Y es que resulta irrelevante la determinación de la naturaleza jurídica tratándose de la prescripción de la acción redhibitoria, dado que, cualquiera sea la naturaleza que se le atribuya, el plazo de prescripción continuará siendo aquel establecido en el artículo 1866 del Código Civil, esto es, de 6 meses para cosas muebles y 1 año respecto de inmuebles, en todos los casos en que leyes especiales o estipulaciones de los contratantes no hubieren ampliado o restringido este plazo.

En lo que se refiere, en cambio, a la incidencia en la tutela del comprador, abogar por la naturaleza rescisoria de la acción redhibitoria, más allá de su pertinencia dogmática, acarrea dos ventajas prácticas. En primer lugar, le otorga al comprador la posibilidad de recurrir a una acción de la que no dispone ordinariamente, ampliando el catálogo de medios de tutela y fortaleciendo el ejercicio de su derecho de opción. En efecto, hasta antes de esta interpretación y, de conformidad al artículo 1889, el comprador solo podía intentar la acción rescisoria por lesión enorme si el justo precio de la cosa que compra es inferior a la mitad del precio que paga por ella y no se concebía la posibilidad que intentara una acción rescisoria propiamente tal, si el vicio redhibitorio que causa el desequilibrio prestacional recae sobre un bien mueble. En segundo lugar, como tal constatación permite explicar que el legislador no ha contemplado una acción especial de resolución o de nulidad relativa en los artículos 1857 y 1860, soluciona los problemas de concursos entre la acción redhibitoria y de aquella derivada de la nulidad relativa, por una parte, y dicha acción y la resolución, por otra $^{112}$, dado que no cobra aplicación el principio de especialidad, toda vez que se trataría de acciones diversas que proceden respecto de supuestos distintos.

\footnotetext{
111 La misma insuficiencia se aprecia tratándose de la lesión enorme, dado que la expresión "rescisión" no puede equipararse a la nulidad relativa, pues, como ya lo hemos precisado, aquella no constituye un vicio del consentimiento en nuestro Código.

112 Problema que ya había sido denunciado por De la Maza (2014) p. 148.
} 
Finalmente, en cuanto al régimen aplicable a la rescisión, este se asimila más al de la resolución que al de la nulidad, en lo que respecta a los efectos, porque, al igual que en esta última, estos se producen hacia el futuro, como se desprende de los artículos 94, 1894 y 1895 del Código Civil, relativos a la rescisión del decreto de posesión definitiva de los bienes del desaparecido y la rescisión por lesión enorme en la compraventa, respectivamente, en que el legislador utiliza tal expresión en su sentido técnico. Y es que, al no existir vicio del consentimiento, como acontece tratándose de la nulidad, no procede el efecto retroactivo que ella acarrea. Por consiguiente, produce un efecto restitutorio, pues deja a las partes en la misma situación en que se encontrarían si no se hubiera celebrado el acto o contrato rescindido ${ }^{113}$, que se deriva de su carácter originario, aplicándose respecto de terceros las reglas particulares de la rescisión stricto sensu contenidas en dichos artículos ${ }^{114}$.

Con todo, nos encontramos ante un supuesto de rescisión que ciertamente reviste algunas particularidades. En efecto, se trata de una acción de ejercicio alternativo, como se desprende expresamente de los artículos 1857 y 1860 del Código Civil, y no subsidiario como es la regla general ${ }^{115}$, toda vez que el comprador puede optar entre la acción redhibitoria y la rebaja del precio en el supuesto que el vicio oculto no sea grave o incluso, como se desprende del artículo 1861, por la sola indemnización si ha existido una infracción dolosa o con culpa grave del deber precontractual de informar los vicios redhibitorios de los que adolece la cosa ${ }^{116}$. Por otra parte, su propósito no es proteger al vendedor que recibe un precio inferior a la mitad del justo precio de la cosa que vende, sino al comprador que paga un precio excesivo en atención a la utilidad que le reportará la cosa defectuosa que adquie$\mathrm{re}^{117}$. De otro lado, a diferencia de lo que ocurre en el supuesto del artículo 1890, el vendedor no puede ofrecerle al comprador la conservación del contrato, completando el justo precio con la deducción de una décima parte, ya que es este último quien decide si opta por la acción redhibitoria o la quanti minoris, en la medida que los vicios sean graves ${ }^{118}$.

Lo cierto es que tales particularidades no obstan a que aboguemos por calificar a la acción redhibitoria como rescisoria por lesión enorme cuando recae sobre inmuebles o rescisoria propiamente tal, en aquellos casos que el vicio redhibitorio afecta a un bien mueble, dado que subsisten los argumentos que hemos formulado precedentemente para arribar a tal conclusión, pues seguimos ante un desequilibrio originario grave en que el legislador expresamente confiere tal acción con el propósito que el comprador pueda restablecer la simetría prestacional que el vicio redhibitorio de la cosa ha ocasionado. Si estamos en lo co-

\footnotetext{
113 De Castro (1985) p. 527, Martín (1995) pp. 221-223, Alcalde (2010) pp. 75-76 y Alberruche (2010) pp. 199-203.

114 Los autores que abogan por la noción que amalgama la rescisión con la nulidad, postulan que, en aquello no previsto por el régimen rescisorio, se aplican las normas propias de la nulidad (BARAONA (2008) p. 667 y Alcalde (2010) p. 73).

115 De Castro (1985) p. 523, Martín (1995) pp. 223-228, De Verda (2009) p. 301, Alcalde (2010) p. 74 y Alberruche (2010) pp. 183-187, quien explica que tal carácter no pretende graficar una prelación de acciones sino que la primera finalidad es restablecer el equilibrio contractual y reparar el perjuicio.

116 En tal sentido en la doctrina nacional GuZMán (2007) pp. 103-116, p. 457, Oviedo (2014a) pp. 237-274, De la Maza (2014) p. 146 y López (2016) pp. 659-683.

117 De Verda (2009) p. 300.

118 De Verda (2009) p. 301.
} 
rrecto, se trataría de un supuesto de tutela precontractual, toda vez que evidencia la ruptura del sinalagma genético u originario, pues es a la época de celebración del contrato que surge la desproporción de las prestaciones recíprocas, agregándose a la nulidad, indemnización y la adaptación del contrato, cuya articulación como piezas de un sistema de tutela precontractual no ha sido abordado en la civilística nacional y que, por lo mismo, conviene comenzar a analizar.

\section{CONCLUSIONES}

De lo expuesto en los párrafos precedentes es posible arribar a las siguientes conclusiones:

1. Una revisión de la doctrina nacional evidencia que aún no se ha asentado una postura definitiva en torno a la naturaleza jurídica de la acción redhibitoria, oscilando los planteamientos entre su carácter resolutorio y anulatorio, en virtud de argumentos que resultan discutibles, toda vez que no se trata de una acción por incumplimiento ni el vicio redhibitorio es coincidente con el error sustancial, en circunstancias que dogmáticamente es más acertado abogar por su naturaleza rescisoria en sentido técnico estricto.

2. Es posible sustentar que se trata de una acción rescisoria por lesión enorme si el vicio redhibitorio recae sobre un inmueble, dado que, al igual que la acción redhibitoria, persigue el restablecimiento del equilibrio contractual originario, es de ejercicio objetivo, procede respecto de casos de desequilibrio prestacional grave, expresamente regulados por el legislador y también se encuentra proscrita tratándose de ventas realizadas por el ministerio de la justicia. En el evento que el vicio afecte a un mueble, sigue siendo rescisoria, toda vez que estamos ante un desequilibrio originario grave en que el legislador expresamente confiere tal acción con el propósito que el comprador pueda restablecer la simetría prestacional que el vicio redhibitorio de la cosa ha ocasionado.

3. Concebir la acción redhibitoria como rescisoria incide favorablemente en el sistema de protección de comprador, pues le otorga la posibilidad de recurrir a una acción de la que no dispone ordinariamente, ampliando el catálogo de medios de tutela y erradicando el concurso entre ella y las acción resolutoria y de nulidad relativa, cuya solución ha oscilado entre aplicar el principio de especialidad o reconocer al acreedor la opción entre ellas, dividiendo innecesariamente a la doctrina nacional.

4. Atendido que el desequilibrio prestacional se produce al momento de la celebración del contrato, pues a esa época existía el vicio grave y oculto que la hace procedente, la acción redhibitoria integra la tutela precontractual del acreedor, agregándose a la indemnización, nulidad y adaptación del contrato como pieza de un sistema que hasta la fecha ha sido inexplorado en nuestra doctrina y que, por lo mismo, conviene comenzar a explorar.

\section{BIBLIOGRAFÍA CITADA}

Alberruche Díaz-Flores, María Mercedes (2010): La rescisión por lesión en el derecho civil español (Madrid, Editorial La Ley). 
Alessandri Besa, Arturo (2008): La nulidad y la rescisión en el derecho civil chileno. Tomo II (Santiago, Editorial Jurídica, tercera edición actualizada).

Alessandri Rodríguez, Arturo (1918): De la compra-venta y de la promesa de venta. Tomo II (Santiago, Imprenta Litográfica Barcelona).

Alessandri Rodríguez, Arturo (2003): De la compraventa y de la promesa de venta. Tomo II, Vol. I y Vol. II (Santiago, Editorial Jurídica de Chile).

Alcalde Silva, Jaime (2010): "La rescisión en el Código Civil chileno", en Departamento de Derecho Privado Universidad de Concepción (coord.), Estudios de Derecho Civil V (Santiago, AbeledoPerrot LegalPublishing) pp. 48-78.

AlCalde Silva, Jaime (2015): "Bases para una sistematización de los efectos de la resolución por incumplimiento" en Vidal, Álvaro, Severín, Gonzalo, Mejías, Claudia (edits.), Estudios de Derecho Civil X (Santiago, Editorial Thomson Reuters La Ley) pp. 579-600.

Barcia Lehmann, Rodrigo (2007): Lecciones de derecho civil chileno. De las fuentes de las obligaciones. Tomo II (Santiago, Editorial Jurídica de Chile).

Barrientos Camus, Francisca María (2011): "El vicio de la cosa comprada. La noción de vicio redhibitorio en el régimen de saneamiento del Código Civil y la Ley sobre Protección de los Derechos de los Consumidores", en De La Maza Gazmuri, Iñigo (coord.), Incumplimiento Contractual. Nuevas Perspectivas, Cuadernos de Análisis Juridico, Colección Derecho Privado, VII (Santiago, Ediciones Universidad Diego Portales) pp. 363-385.

Barrientos Camus, Francisca María (2015): "Una mirada a la calidad de las cosas en la praxis judicial. Su evolución desde los vicios redhibitorios hasta la inejecución imperfecta de la obligación de entrega”, en Henríquez Herrera, Ian (coord.), La compraventa. Nuevas perspectivas doctrinarias (Santiago, Editorial Thomson Reuters, La Ley) pp. 135-154.

Baraona GonzÁlez, Jorge (2008): "La acción redhibitoria como acción de nulidad" en GuZmán, Alejandro (ed.), Estudios de Derecho Civil III (Santiago, Editorial LegalPublishing) pp. 659-669.

BARAONA GONZÁlEZ, Jorge (2012): La nulidad de los actos jurídicos: consideraciones históricas y dogmáticas (Bogotá, Editorial Pontificia Universidad Javeriana-Ibáñez).

Barros Bourie, Enrique (2006): Tratado de responsabilidad extracontractual (Santiago, Editorial Jurídica de Chile).

Barros Errázuriz, Alfredo (1932): Curso de derecho civil. Segundo año. Segunda parte. Tratado de los contratos y demás fuentes de las obligaciones. Vol. III (Santiago, Editorial Nascimento, cuarta edición).

Bercovitz Rodríguez-Cano, Rodrigo (1969): "La naturaleza de las acciones redhibitoria y estimatoria en la compraventa", Anuario de Derecho Civil, Vol. 22, fascículo 4: pp. $777-$ 838.

Bello, Andrés (1888): Obras Completas. Tomo XII (Santiago, impreso por Pedro G. Ramírez).

BetTi, Emilio (2000): Teoría del negocio jurídico (trad. Antonio Martín Pérez, Granada, Editorial Comares). 
Capitant, Henri (1927): De la cause des obligations (Contrats, Engagements unilateraux, Legs) (Paris, Editorial Dalloz).

Caprile Biermann, Bruno (2008): "Las acciones del comprador insatisfecho: el cúmulo actual (Ley de protección al consumidor, vicios redhibitorios, error sustancial, resolución por incumplimiento) y la tendencia al deber de conformidad en el Derecho Comparado", en Mantilla, Fabricio y Pizarro, Carlos (coords.) en Estudios de Derecho Privado en homenaje al profesor Christian Larroumet (Santiago, Editorial Fundación Fernando Fueyo) pp. 571-601.

CÉLICE, Raymond (1920): El error en los contratos (trad. César Camargo y Marín, Madrid Editorial Góngora).

Coing, Helmut (1996): Derecho Privado europeo T. I (trad. Antonio Pérez Martín, Madrid, Fundación Cultural del Notariado).

Coing, Helmut (1996): Derecho Privado europeo T. II (trad. Antonio Pérez Martín, Madrid, Fundación Cultural del Notariado).

Contardo GonZÁlez, Juan Ignacio (2015): Indemnización y resolución por incumplimiento (Santiago, Editorial Thomson Reuters La Ley).

Cumyn, Michell (2002): La validité du contrat suivant le droit strict ou l' équite: étude historique et comparée des nullités contractuel (Paris, Editorial L.G.D.J.).

De Castro y Bravo, Federico (1985): El negocio jurídico (Madrid, Editorial Civitas).

De la Maza Gazmuri, Iñigo (2006): "Falta de conformidad, vicios redhibitorios e incumplimiento", Revista Chilena de Derecho Privado, N 6: pp. 155-159.

De la Maza Gazmuri, Iñigo (2010): “A propósito del artículo 1861", en Departamento de Derecho Privado Universidad de Concepción (coord.), Estudios de Derecho Civil V (Santiago, AbeledoPerrot LegalPublishing) pp. 455-469.

De la Maza Gazmuri, Iñigo (2012a): "Configuración de la obligación de entregar a través de la autonomía privada: derechos de terceros", Revista de Derecho de la Pontificia Universidad Católica de Valparaíso, Vol. 39: pp. 95-114.

De la Maza Gazmuri, Iñigo (2012b): "El régimen de los cumplimientos defectuosos en la compraventa”, Revista Chilena de Derecho, Vol. 39, N 3: pp. 629-663.

De la Maza Gazmuri, Iñigo (2014): "La tutela del comprador frente a la ausencia de calidades presupuestas en la cosa", Revista de Derecho de la Pontificia Universidad Católica de Valparaíso, No 43: pp. 117-159.

De la Maza Gazmuri, Iñigo (2015): "La conformidad de la cosa vendida: adecuación material”, Revista de Derecho de Valdivia, Vol. 28, N 1: pp. 79-100.

De Verda y Beamonte, José Ramón (2009): Saneamiento por vicios ocultos. Las acciones edilicias (Navarra, Editorial Aranzadi Thomson Reuters, segunda edición).

Devoto Berrimán, Carolina (2004): "La lesión enorme ante la legislación comparada y código civil chileno", Temas de Derecho, año 19, Nº 1 y 2: pp. 147-174.

Díez Duarte, Raúl (2009): La compraventa (Santiago, Editorial El Jurista, segunda edición).

Díez-Picazo, Luis (2007): Fundamentos del Derecho Civil Patrimonial: Introducción a la teoría del contrato. Tomo I (Navarra, Editorial Civitas, sexta edición actualizada). 
Díez-Picazo, Luis (2010): Fundamentos del Derecho Civil Patrimonial. Las particulares relaciones obligatorias. Tomo IV (Pamplona, Editorial Aranzadi).

Domínguez Águila, Ramón (2005): "Consideraciones sobre la lesión, en especial en el Derecho chileno", Revista de Derecho Universidad de Concepción, N's 217-218: pp. 7-34.

Domínguez Águila, Ramón (2012): Teoría general del negocio jurídico (Santiago, Editorial Jurídica de Chile, segunda edición).

DOMAT, Jean (1841a): Las leyes civiles en su orden natural. 1a parte, Libro $4^{\circ}$, Título VI (Barcelona, Imprenta de José Tauló).

Domat, Jean (1841b): Las leyes civiles en su orden natural. $1^{a}$ parte, Libro $4^{\circ}$, Titulo II, Sección IX (Barcelona, Imprenta de José Tauló).

D’Ors, Álvaro (1997): Derecho Privado Romano (Pamplona, Editorial Universidad de Navarra, novena edición).

Ducci Claro, Carlos (1995). Derecho Civil: Parte General (Santiago, Editorial Jurídica de Chile, cuarta edición).

ESCRICHE, Joaquín (1998): Diccionario razonado de legislación y jurisprudencia. T. III (Bogotá, Editorial Temis, segunda edición).

Espinar Lafuente, Francisco (1969): "Resolución e indemnización en las obligaciones recíprocas", en Fuenmayor, A.- Sancho, F. (edits.) en Estudios de Derecho Civil en honor del Prof. Castán Tobeñas, T. II (Pamplona, Ediciones Universidad de Navarra) pp. 111-164.

Fenoy Picón, Nieves (2006): El sistema de protección del comprador (Madrid, Editorial Colegio de Registradores de la Propiedad y Mercantiles de España).

Fenoy Picón, Nieves (2011): "La modernización del régimen del incumplimiento del contrato: Propuesta de la Comisión General de Codificación. Parte Segunda: los remedios por incumplimiento", Anuario de Derecho Civil, Vol. 64, fascículo 4: pp. 1481-1685.

Ferrante, Alfredo (2012): La reducción del precio en la compraventa (Navarra, Cizur Menor, Thomson Reuters-Aranzadi).

FERRANTE, Alfredo (2014): “¿Es correcta la elección del método de cálculo de la reducción del precio en los principios latinoamericanos de contratos?", Revista Chilena de Derecho Privado, $\mathrm{N}^{\circ}$ 22: pp. 9-49.

Figueroa Yáñez, Gonzalo (2011): "Rescisión, Resolución y Redhibición: ¿Puede hablarse de un "cúmulo de acciones"?", en Estudios de Derecho Privado. Libro Homenaje al jurista René Abeliuk Manasevich (Santiago, Editorial Jurídica de Chile) pp. 111-120.

García Pérez, Carmen Leonor (2014): "Las acciones edilicias y el artículo 1.124 del Código Civil”, en González Pacanowska, Isabel-García Pérez, Carmen Leonor (coords.), Estudios sobre Incumplimiento y Resolución (Navarra, Thomson Reuters Aranzadi) pp. 427-472.

Gaspar Lera, Silvia (2014): "Formación de la voluntad contractual, vicios del consentimiento y remedios", en Parra LuCÁn, María Ángeles (dir.), Negociación y perfección de los contratos (Navarra, Editorial Thomson Reuters Aranzadi) pp. 269-315.

GuZMÁn Brito, Alejandro (1999): "Las relaciones entre la compraventa, la permuta y la lesión enorme: del derecho romano al Código Civil de Chile", Revista de Historia de Derecho Privado, $\mathrm{N}^{\circ}$ 2: pp. 7-64). 
GuZMÁn Brito, Alejandro (2007): "Sobre la relación entre las acciones de saneamiento de los vicios redhibitorios y las acciones comunes de indemnización, con especial referencia a su prescripción (opinión profesional)", Revista Chilena de Derecho Privado, No 9: pp. 95-119.

Guzmán Brito, Alejandro (2013): Derecho Privado Romano. Tomo II (Santiago, Editorial LegalPublishing Thomson Reuters, segunda edición).

Larroucau Torres, Jorge (2015): "Vicios, acciones y prueba en la compraventa", Revista de Derecho Universidad Católica del Norte, Año 22, N 1: pp. 259-306.

López Díaz, Patricia Verónica (2014a): "El aliud pro alio: un supuesto de indemnización de daños autónoma o exclusiva frente al incumplimiento del deudor”, en Turner SaELZER, S. y Varas Braun, J. (coords.), Estudios de Derecho Civil IX (Santiago, Editorial Thomson Reuters La Ley) pp. 605-624.

López Díaz, Patricia Verónica (2014b): "La autonomía de la indemnización de daños en la jurisprudencia nacional reciente: ¿un cambio de paradigma?”, Revista Chilena de Derecho Privado, No 23: pp. 139-207.

López Díaz, Patricia Verónica (2015a): "Por una noción amplia de lesión enorme en el Código Civil Chileno: una relectura a partir del principio de equilibrio contractual y la idea de excesiva desproporción contenida en el Borrador de los Principios Latinoamericanos de derecho de los contratos", en Vidal, Álvaro, Severín, Gonzalo, Mejías, Claudia (edits.), Estudios de Derecho Civil X (Santiago, Editorial Thomson Reuters LegalPublishing) pp. 699-723.

López Díaz, Patricia Verónica (2015b): "El principio de equilibrio contractual en el Código Civil chileno y su particular importancia como fundamento de algunas instituciones del moderno derecho de las obligaciones en la dogmática nacional", Revista Chilena de Derecho Privado, No 25: pp. 115-181.

López Díaz, Patricia Verónica (2016): "La indemnización de daños por vicios redhibitorios como medio de tutela precontractual autónomo en el Código Civil Chileno: un tópico cuya procedencia y alcance aún permanecen difusos", en UNIVERSIDAD DE CONCEPCIÓN, Estudios de Derecho Civil XI (Santiago, Editorial Thomson Reuters LegalPublishing) pp. 659-683.

López Díaz, Patricia Verónica (2017): "La noción de lesión enorme en el Código Civil chileno: una manifestación del equilibrio contractual orientada prevalentemente a configurar la adaptación del contrato como medio de tutela precontractual", en CONTARDO González, Juan Ignacio y de la Maza Gazmuri, Iñigo (dirs.), La Compraventa. Estudios (Santiago, Editorial Thomson Reuters LegalPublishing) pp. 657-708.

Luminoso, Angelo (2009): La Compravendita. Corso di diritto civile (Torino, Editorial Giappichelli, sexta edición).

Llácer Matacás, María Rosa (1992): Saneamiento por vicios ocultos en el Código Civil: su naturaleza jurídica (Barcelona, Editorial Bosch).

Manresa y Navarro, José María (1931): Comentarios al Código Civil español. Tomo X (Madrid, Editorial REUS, cuarta edición).

Martín Pérez, José Antonio (1995): La rescisión del contrato (en torno a la lesión contractual $y$ el fraude de acreedores) (Barcelona, Editorial Bosch). 
Merello, Italo (1979): "Antecedentes históricos sobre algunos aspectos del régimen de la lesión enorme en el proceso de formación del Código Civil chileno", Revista de Estudios Histórico-Jurídicos, $\mathrm{N}^{\circ}$ 4: pp. 89-117

MejÍAs Alonzo, Claudia (2011): El incumplimiento resolutorio en el Código Civil (Santiago, Editorial AbeledoPerrot LegalPublishing).

Mejías Alonzo, Claudia Carolina (2016): "Una revisión crítica de los efectos de la resolución por incumplimiento y una propuesta de solución”, Ius et Praxis, año 22, $\mathrm{N}^{\circ} 1$ : pp. 271-322.

Morales Moreno, Antonio Manuel (1980): "El alcance protector de las acciones edilicias", Anuario de Derecho Civil, Vol. 33, N 3: pp. 585-686.

Morales Moreno, Antonio Manuel (1991): “Comentario al art. 1486 CC”, en Paz-Arés, Cándido-Díez-Picazo, Luis, Bercovitz, Rodrigo y Salvador, Pablo (dirs.), Comentario del Código Civil. Tomo II (Madrid, Ministerio de Justicia) pp. 959-962.

Morales Moreno, Antonio Manuel (2006): "Adaptación del código civil al derecho europeo: La compraventa”, en Morales Moreno, Antonio Manuel, La modernización del Derecho de obligaciones (Navarra, Editorial Thomson Civitas) pp. 93-144.

Morales Moreno, Antonio Manuel (2011): “¿Es posible construir un sistema precontractual de remedios? Reflexiones sobre la Propuesta de Modernización del Derecho de Obligaciones y Contratos en el marco del Derecho europeo", en Albiez Dohrmann, Klaus Jochen (dir.), Palazón Garrido, María Luisa-Méndez Serrano, María del Mar (coords.), Derecho Privado Europeo y Modernización del Derecho Contractual en España (Barcelona, Editorial Atelier) pp. 400-422.

Morales Moreno, Antonio Manuel (2012): "Tres modelos de vinculación del vendedor en las cualidades de la cosa", Anuario de Derecho Civil, No 65, fasc. 1: pp. 5-28.

Mosquera Rojas, Loreto (1998): La rescisión en el Código Civil chileno. Tesis de Licenciatura en Ciencias Jurídicas y Sociales, Pontificia Universidad Católica de Chile (Santiago, inédita).

Mucius Scaevola, Quintus (1906): Código Civil: concordado y comentado extensamente con arreglo a la edición oficial. Arts. 1445-1541, Tomo XXXIII (Madrid, Establecimiento Tipográfico de P. Apalategui, Pozas 12).

Oviedo Albán, Jorge (2010): "Sobre el concepto de vicio redhibitorio en la compraventa. Análisis comparado de la jurisprudencia chilena y colombiana”, Revista Chilena de Derecho, Vol. 37, $\mathrm{N}^{\circ}$ 2: pp. 241-269.

Oviedo Albán, Jorge (2014a): "Indemnización de perjuicios por vicios redhibitorios en el Código Civil chileno-colombiano", Revista Vniversitas, No 129: pp. 237-274.

Oviedo Albán, Jorge (2014): "La protección del comprador ante los vicios ocultos de la cosa entregada: del derecho romano a los instrumentos contemporáneos sobre contratos", Revista de Derecho de la Pontificia Universidad Católica de Valparaiso, No 43: pp. 201-240.

Oviedo Albán, Jorge (2015): "Los requisitos del vicio redhibitorio en la compraventa según el Código Civil”, en Henríquez Herrera, Ian (coord.), La compraventa. Nuevas perspectivas doctrinarias (Santiago, Editorial Thomson Reuters, La Ley) pp. 107-134.

Oviedo Albán, Jorge (2016): "Los requisitos del vicio redhibitorio en la compraventa según el Código Civil chileno-colombiano", Revista de Derecho Privado, Universidad Externado de Colombia, N 30: pp. 129-169. 
Peñailillo Árevalo, Daniel (2000): "La revisión judicial de obligaciones y contratos en la reforma del Código Civil (La lesión y la imprevisión)", Revista de Derecho Universidad de Concepción, año 68, N²08: pp. 209-237.

Pizarro Wilson, Carlos (2012): "Contra el efecto retroactivo de la resolución por incumplimiento contractual”, en Elorriaga, Fabián (coord.), Estudios de Derecho Civil VII (Santiago, Editorial AbeledoPerrot LegalPublishing Thomson Reuters) pp. 449-460.

Pothier, Robert Joseph (1861): Oeuvres de Pothier. Annoteés et mises en corrélation avec le code civil et la législation actuelle par M. Bugnet, T. X. Traité de la procédure civile. Traité de la procédure criminelle (Paris, Impresion L' Empereur).

Prado López, Pamela (2015): "La cuantificación de la rebaja del precio en la acción quanti minoris", Ius et Praxis, año 21, $\mathrm{N}^{\circ} 1$ : pp. 617-650.

Rodríguez Grez, Pablo (1995): Inexistencia y nulidad en el Código Civil chileno. Teoría bimembre de la nulidad (Santiago, Editorial Jurídica de Chile).

Santos Briz, Jaime (1973): Derecho civil. Teoría y práctica. Derecho de obligaciones. Los contratos en particular. Tomo IV (Madrid, Editorial Revista de Derecho Privado).

Troncoso Larronde, Hernán y Álvarez Cid, Carlos (2014): Contratos (Santiago, Editorial Thomson Reuters La Ley, sexta edición).

Vaquer Aloy, Antoni (2011): "El principio de conformidad: ¿supraconcepto en el derecho de obligaciones?", Anuario de Derecho Civil, Vol. N 64, fasc. 1: pp. 5-39.

\section{JURISPRUDENCIA CITADA}

Cecinas La Preferida con Comercial Salinak Ltda. (2005): Corte Suprema, 27 de julio de 2005 (casación en el fondo) en www.vlex.cl, NVLEX-255209958.

Larzabal Beraza con Sociedad Inmobiliaria Talasia Ltda. (2008): Corte Suprema, 27 de marzo de 2008 (casación en el fondo) en www.vlex.cl, No VLEX-332708178.

SERVICIOS DE Impresión J.A. AmenABar LtDA. con Fuentes Riquelme (2008): Corte Suprema, 4 de agosto de 2008 (casación en el fondo) en www.microjuris.com, MJJ17851).

agF Allianz Compañía de Seguros Generales S.A. con Le Torneau Inc. (2010): Corte Suprema, 8 de Julio de 2010 (casación en el fondo) en www.microjuris.com, MJJ24291.

Toro Mancilla con Banco Santander Chile (2011): Corte Suprema, 26 de septiembre de 2011 (casación en el fondo) en www.Legalpublishing.cl, Nº CL/JUR/9809/2011. 